\title{
The role of anomalous SST and surface fluxes over the Southeastern North Atlantic in the explosive development of windstorm Xynthia
}

Article

Accepted Version

Ludwig, P., Pinto, J. G., Reyers, M. and Gray, S. L. (2014) The role of anomalous SST and surface fluxes over the Southeastern North Atlantic in the explosive development of windstorm Xynthia. Quarterly Journal of the Royal Meteorological Society, 140 (682). pp. 1729-1741. ISSN 1477870X doi: https://doi.org/10.1002/qj.2253 Available at https://centaur.reading.ac.uk/34425/

It is advisable to refer to the publisher's version if you intend to cite from the work. See Guidance on citing.

Published version at: http://onlinelibrary.wiley.com/doi/10.1002/qj.2253/abstract

To link to this article DOI: http://dx.doi.org/10.1002/qj.2253

Publisher: Royal Meteorological Society

All outputs in CentAUR are protected by Intellectual Property Rights law, including copyright law. Copyright and IPR is retained by the creators or other copyright holders. Terms and conditions for use of this material are defined in the End User Agreement. 


\section{www.reading.ac.uk/centaur}

\section{CentAUR}

Central Archive at the University of Reading

Reading's research outputs online 


\title{
The role of anomalous SST and surface fluxes over the
}

\section{Southeastern North Atlantic in the explosive development of windstorm Xynthia}

\author{
Patrick Ludwig* \\ Institute for Geophysics and Meteorology, University of Cologne, Cologne, Germany
}

Joaquim G. Pinto

Department of Meteorology, University of Reading, Reading, United Kingdom; and Institute for Geophysics and Meteorology, University of Cologne, Cologne, Germany

\begin{abstract}
Mark Reyers
Institute for Geophysics and Meteorology, University of Cologne, Cologne, Germany
\end{abstract}

Suzanne L. Gray

Department of Meteorology, University of Reading, Reading, United Kingdom

\begin{abstract}
* Corresponding author: Patrick Ludwig, Institute for Geophysics and Meteorology, University of Cologne, Kerpener Str. 13, 50937 Cologne, Germany. E-mail:

pludwig@meteo.uni-koeln.de
\end{abstract}

This article has been accepted for publication and undergone full peer review but has not been through the copyediting, typesetting, pagination and proofreading process, which may lead to differences between this version and the Version of Record. Please cite this article as doi: $10.1002 /$ qj.2253

This article is protected by copyright. All rights reserved. 


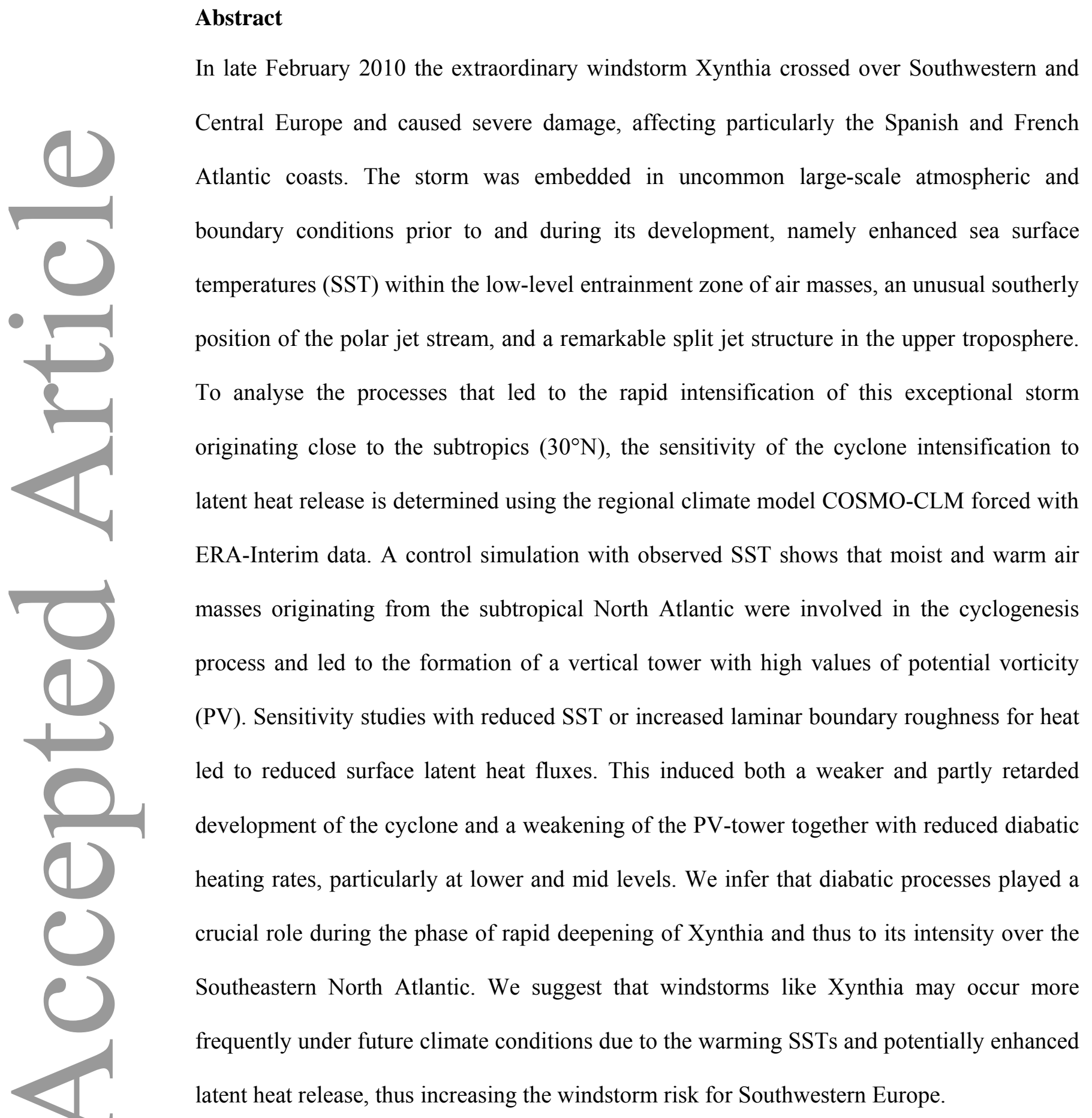

This article is protected by copyright. All rights reserved. 


\section{Introduction}

Mid-latitude winter storms are frequent phenomena, which occasionally lead to severe damage and strong socio-economic impacts over Europe (e.g. Lamb, 1991; SwissRe, 2008). The majority of such extreme extratropical cyclones originate in a region between Newfoundland and Iceland and have a north-eastward orientated track. This area is also known as the North Atlantic storm track region (e.g. Hoskins and Valdes, 1990). Most of these extreme cyclones undergo explosive cyclogenesis over the North Atlantic basin before they hit Europe (e.g. windstorms Lothar and Martin in 1999, Jeanett in 2002, Kyrill in 2007, and Klaus in 2009; cf. Wernli et al., 2002; Liberato et al., 2011; Fink et al., 2012) ${ }^{1}$.

In late February and the first days of March 2010 windstorm Xynthia affected South-western and Central Europe. This explosively deepening storm exhibited an uncommon track compared to typical extreme cyclones (c.f. Trigo, 2006; Pinto et al., 2009). Xynthia originated from the subtropical eastern North Atlantic around $30^{\circ} \mathrm{N}$ where there were anomalously high sea surface temperatures (SSTs) even for this subtropical region, and followed an unusual southwest to northeast track passing close to the coast of the Iberian Peninsula (Fig. 1(a)).

Severe winds were reported over large parts of South-western Europe (Liberato et al., 2013; their Fig. 2). The windstorm reached a minimum measured core pressure of $969 \mathrm{hPa}$ (according to ERA-Interim reanalysis data), and gales reached up to $200 \mathrm{~km} \mathrm{~h}^{-1}$ in exposed mountainous areas (Bedacht and Hofherr, 2011). A total of 47 fatalities were reported because of the storm surge and associated dike bursts that caused 50000 ha of flooded land when the storm reached the French coast (Lumbroso and Vinet, 2011). Losses for France, Spain and Germany were estimated at $€ 3.10 \mathrm{bn}, € 250 \mathrm{~m}$, and $€ 750 \mathrm{~m}$, respectively (Bedacht

\footnotetext{
${ }^{1}$ Storm names employed herein are as given by the Freie Universität Berlin and as used by the German Weather Service. Source: http://www.met.fu-berlin.de/adopt-a-vortex/historie/
}

This article is protected by copyright. All rights reserved. 
and Hofherr, 2011). A detailed description of the socio-economic impacts can be found in Liberato et al. (2013).

Many factors associated with the development of extratropical cyclones have been explored in the literature. Primarily, a broad baroclinic environment is required (e.g. Hoskins and Hodges, 2002; Wernli et al., 2002; Gray and Dacre, 2006). As a result of thermal wind balance, strong baroclinicity is associated with a strong upper-tropospheric jet stream (Carlson, 1991). Uccellini and Johnson (1979) showed that upper-level divergence at the entrance and exit region of a jet streak is an important factor for rapid cyclogenesis. Baehr et al. (1999) demonstrated that the phase of rapid deepening corresponds to the crossing of the cyclone from the warm to the cold side of the jet stream and its prevailing divergence areas. Diabatic processes like the release of latent heat are also important for the evolution of extratropical storms (Uccellini, 1990). Previous studies have demonstrated that latent heat release by cloud condensation processes can be a crucial energy source for the storm evolution (Danard, 1964; Chang et al., 1982; Robertson and Smith, 1983). By applying a novel version of the surface pressure tendency equation to reanalysis data, Fink et al. (2012) were able to quantify the role of diabatic processes for five recent windstorms. For Xynthia and two other storms diabatic processes were found to contribute more to the observed core pressure fall than horizontal temperature advection. Latent heating has often been identified to increase the growth rate of cyclones by baroclinic instability (e.g. Davis and Emanuel, 1991), and in some cases it even dominates the cyclogenesis process. Plant et al. (2003) and Ahmadi-Givi et al. (2004) showed that midlevel latent heating was crucial for two so-called 'type C' cyclones as defined by Deveson et al. (2002). In these cases, the latent heating acts as a 'dynamical surrogate' (Snyder and Lindzen, 1991) for the basic-state baroclinicity, enabling cyclones to develop in regions of weak surface thermal anomalies. This is consistent with the higher proportion of type $\mathrm{C}$ cyclones found in the east compared with the west North 
Atlantic (Dacre and Gray, 2009). The location and orientation of the tracks of extreme extratropical cyclones over the North Atlantic basin are strongly linked to the mode of the North Atlantic oscillation (NAO, e.g. Wanner et al., 2001). The probability of the development of extreme cyclones over the North Atlantic is highest during positive NAO phases (e.g. Raible, 2007; Pinto et al., 2009). Nevertheless, extreme cyclones may also occur during negative NAO phases. In such a negative NAO phase, the polar jet stream is shifted southwards (e.g. Woollings et al., 2010), thus enhancing the probability for severe windstorms affecting Southwestern Europe.

Many studies have pointed out the benefit of using potential vorticity (PV; Hoskins et al., 1985) to analyse the temporal evolution of synoptic systems. Broad areas of high PV values in the upper troposphere (meridionally orientated PV-streamers) have been identified as precursors for cyclonic systems (Massacand et al., 1998; 2001). PV-anomalies are also strongly linked to diabatic processes and anomalously high low-level and mid-level PV values often act as an indicator of latent heat release (cf. Hoskins, 1990; Wernli et al., 2002). The interactions between upper-level PV-anomalies and diabatically induced low-level PVanomalies can lead to an intensification of the cyclogenesis process (Hoskins et al., 1985) and to the formation of a so-called PV-tower with a distinct vertical extension throughout the troposphere (Wernli et al., 2002). Hence, the generation of PV in the low and mid troposphere also plays an important role in cyclone formation (e.g. Reed et al., 1992; Wernli and Davies, 1997), and the vertical PV distribution can be used to analyse the associated diabatic processes. Areas of extensive diabatic heating can be found e.g. in warm conveyor belts of extratropical cyclones, where the ascent of warm and moist air masses lead to huge amounts of latent heat release and the formation of upper-tropospheric negative PV anomalies in addition to the positive PV anomalies at lower levels (Pomroy and Thorpe, 2000). The influence of latent heat release on PV changes in warm conveyor belts and its 
potential influence on the large-scale dynamics is currently a subject of intense research (e.g. Joos and Wernli, 2012; Chagnon et al., 2013). Further, Dacre and Gray (2013) analysed the relationship between atmospheric precursors and extratropical cyclone intensity. For cyclones over the eastern North Atlantic they detected a significant association between the existence of mid-tropospheric PV-anomalies and increased cyclone intensity 48 hours later.

As countries in Southern Europe are rarely affected by severe windstorms, we analyse here the large-scale dynamical conditions supporting the unusual southerly origin and rapid intensification of Xynthia. Regional (rather than global) model studies are required to consider the associated diabatic processes, since the feedback between cyclone intensification and latent heat release is strongly sensitive to horizontal resolution (Willison et al., 2013). The aim of this study is to determine the role of anomalously high SST over the southeastern North Atlantic in the cyclogenesis process of Xynthia by using a regional climate model. Section 2 describes the data and the regional climate model used in this study. A short description of different numerical sensitivity experiments is also given. In section 3, a brief synoptic overview of the large-scale atmospheric conditions prior to and during the occurrence of Xynthia, as well as results of a Lagrangian trajectory analysis are shown. The analysis of the outcomes of the regional numerical simulations is presented in section 4 . The general findings are discussed and summarized in section 5.

\section{Data, analysis tools and numerical model}

ERA-Interim reanalysis data (Dee et al., 2011) from the European Centre for Medium-Range Weather Forecasts (ECMWF) are used to analyse the large-scale atmospheric conditions prior to and during the occurrence of Xynthia. This data is available at six-hourly intervals with a horizontal resolution of $0.75^{\circ} \times 0.75^{\circ}$. To identify the sources of air masses involved in 
the cyclogenesis process a Lagrangian trajectory analysis tool (Noone and Simmonds, 1999; Barras and Simmonds, 2009) is applied to several variables in the ERA-Interim dataset.

For model studies, the non-hydrostatic regional COSMO model (http://www.cosmo-

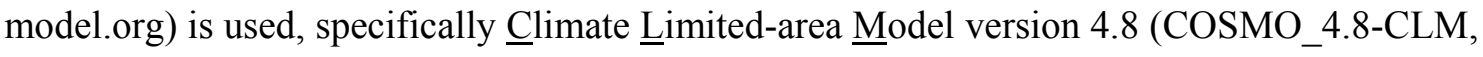
hereafter CCLM; Rockel et al., 2008). The formulation of the dynamical core and physical parameterisations is equal to those of the COSMO-model, which is operationally used by the German Weather Service (DWD). The only difference to the operational model version is that neither data assimilation of observational data nor latent heat nudging of radar data are performed. The ability of CCLM to reproduce extreme windstorms and their characteristics is documented in Born et al. (2012). The model domain (Fig. 1(a), bold black border) covers large parts of Europe and the North Atlantic Ocean, roughly ranging from $70^{\circ} \mathrm{N}$ to $15^{\circ} \mathrm{N}$. This large domain enables us to capture all crucial stages of the evolution of Xynthia, from its deepening phase over the south-eastern North Atlantic to its decay over the Baltic Sea. Due to the large model domain, the simulations are performed with a relatively coarse horizontal resolution (compared to operational limited area weather forecast models) of $0.22^{\circ} \times 0.22^{\circ}$ (approx. $25 \mathrm{~km} \times 25 \mathrm{~km}$ ) and with 35 layers in the vertical. ERA-Interim data is used as boundary conditions. For time step integration, the Runge-Kutta integration scheme is used with a time step of $144 \mathrm{~s}$. CCLM simulations are performed for the $96 \mathrm{~h}$-period from 00UTC 26 February 2010 to 00UTC 2 March 2010.

First, a control simulation with standard physics and undisturbed initial boundary conditions (in particular observed SST) serves as a reference run (CNTRL). Further, five sensitivity experiments are performed to investigate the role of the anomalously high SST and associated latent heat release in the development of Xynthia. In the first two sensitivity experiments (SF5, SF10) the surface heat fluxes and thus the evaporation over a southwestern sub region of the model domain (Fig. 1, thin black box) over the North Atlantic 
Ocean are reduced by modifying the respective empirical model parameters. This sub region comprises the area over which the strongest intensification of Xynthia was identified. Specifically, the laminar boundary roughness for heat at the surface is enhanced; the nondimensional parameter rlam_heat (identified to affect model results by Bellprat et al., 2012) is increased from 1 to 5 (SF5) and 10 (SF10), respectively. The parameter rlam_heat is proportional to the inverse of the transfer coefficient of heat (tch), In turn, tch is directly proportional to the surface latent heat flux. Thus, an increase of rlam_heat will lead to lower tch values and also to reduced surface latent heat fluxes. A sensitivity study by Langland et al. (1996) showed that an increase of the transfer coefficient for the surface latent heat flux leads to an intensified cyclone.

In the other three sensitivity experiments, the SST is stepwise reduced over the sub region defined in Fig. 1. The initial SST is reduced in steps of $1 \mathrm{~K}$ at each model grid point in the sub region relative to that in CNTRL to a maximum reduction of $3 \mathrm{~K}$ (experiments TS1 to TS3). The specific humidity in the boundary layer is assumed to decrease when surface fluxes or initial SST are reduced. To give the specific humidity sufficient time to adjust to modified surface conditions, an initialization run is performed prior each of the sensitivity runs. The initialisation runs are started on 24 February 00UTC (two days prior to the start time of the sensitivity runs), and provide adapted boundary layer humidity fields. Analysis of simulations with different lengths of initialisation runs reveals that a lead-time of 48 hours is sufficient for humidity adjustment. Afterwards, the sensitivity runs are performed using these adjusted boundary layer humidity fields as initial conditions at 26 February 00UTC. To restrict the adjustment of humidity to the boundary layer, a spectral nudging procedure (von Storch et al., 2000) is applied to the initialisation runs. By using this technique, the large-scale atmospheric flow fields are kept close to the driving reanalysis fields ensuring that the upperlevel forcing differs only marginally from that in the control simulation. A similar approach 
of humidity adjustment for initializing RCMs has e.g. been applied by Etienne et al. (2013) for simulations over lakes in Switzerland. Surface and upper-air analysis charts provided by DWD (German weather service) as well as reports from two synoptic stations (Porto, WMO: 08545, $8.68^{\circ} \mathrm{W}, 41.23^{\circ} \mathrm{N}$ and Chassiron, WMO: $07314,1.41^{\circ} \mathrm{W}, 46.05^{\circ} \mathrm{N}$ ) are used to validate the CNTRL simulation. The locations of both synoptic stations are indicated in Fig. $5(a)$.

To reveal the influence of diabatic processes (cf. section 5) we calculated potential vorticity (PVU) and the diabatic heating rate (DHR). The calculation of potential vorticity on isobaric surfaces follows Dickinson et al. (1997):

$$
P V=-g \frac{\partial \theta}{\partial p}\left(f+\frac{\partial v}{\partial x}-\frac{\partial u}{\partial y}\right)+g\left(\frac{\partial v}{\partial p} \frac{\partial \theta}{\partial x}-\frac{\partial u}{\partial p} \frac{\partial \theta}{\partial y}\right)
$$

Here, $g$ is gravity, $\theta$ represents the potential temperature, $f$ is the Coriolis parameter, $p$ is the pressure level and $u$ and $v$ represent the zonal and meridional components of the wind, respectively. The DHR (also section 5) follows Berrisford (1988) and assumes that condensation occurs where ascending air is (nearly) saturated:

$$
\dot{\theta}=\frac{-\frac{L}{c_{p}} \frac{\kappa \theta \omega}{p} \frac{d q_{s}}{d T}}{1+\frac{L}{c_{p}} \frac{d q_{s}}{d T}}\left\{\left\{1-\exp \left(\frac{h_{0}-h}{5}\right)\right\}\right.
$$

Thereby it is assumed that the vertical velocity $\omega<0$ (ascending motion) and the relative humidity $h>h_{0}=80 \% . L$ denotes the latent heat of condensation of water, $c_{p}$ the specific heat capacity of water vapour at constant pressure, $\kappa$ the ratio of $\mathrm{R}$ (gas constant) and $\mathrm{c}_{\mathrm{p}}$, and $q_{s}$ the saturation mixing ratio. The latter term accounts for potential saturation on the sub-grid scale (cf. Grams et al. 2011).

This article is protected by copyright. All rights reserved. 


\section{Synoptic overview of the storm development}

A description of the large-scale atmospheric conditions prior to and during the occurrence of Xynthia is presented in this section. Brief descriptions of Xynthia can also be found in Rivière et al. (2012) and Liberato et al. (2013). The analysis is based on ERA-Interim reanalysis data. Xynthia was initially identified on 25 February over the subtropical North Atlantic (cf. Fig. 1(a)). Its development was associated with a huge snowstorm on the east coast of the United States, which modified the upper-level PV-distribution and formed a PVstreamer in the vicinity of developing Xynthia (Piaget, 2011). In the following days, Xynthia underwent explosive cyclogenesis and reached its lowest core pressure close to the French Atlantic coast, before it dissipated over the Baltic Sea.

As reported by Osborn (2011), the winter months prior Xynthia were characterized by a record-breaking negative phase of the NAO. Correspondently, the polar jet was shifted southward during most of the winter 2009/2010 (Santos et al., 2013), and was mainly located around the southern peak of its trimodal climatological distribution (Woollings et al., 2010). From 4-28 February, the polar jet was shifted to a region between $30^{\circ} \mathrm{N}$ and $40^{\circ} \mathrm{N}$ (Santos $e t$ al., 2013; their Fig. 1), thus forming favourable conditions for strong cyclogenesis around this latitudinal band.

A positive SST anomaly existed over most of the subtropical North Atlantic during February 2010 (Fig. 2). Figure 2 also shows the presence of long-lived Gulf Stream eddies which can be inferred from the series of alternating cold and warm anomalies in the Gulf Stream region. The SST anomaly has its maximum (exceeding $2 \mathrm{~K}$ ) close to the West African coast, a region that is usually characterized by upwelling of cold water, as can be seen in the climatological SST mean (black isolines in Fig. 2). It is also mostly above twice the standard deviation of the 30-year climatology as derived from ERA-Interim (dotted areas in Fig. 2). Hence, an 
increased amount of available moisture can be assumed over the subtropical North Atlantic, which in turn can lead to an enhanced release of latent heat when these air masses are lifted, potentially playing a crucial role in the development of Xynthia. Within these prevailing atmospheric conditions, a catastrophic frontal rainfall event hit the island of Madeira just one week before the occurrence of Xynthia (Fragoso et al., 2012). The capital Funchal reported a daily precipitation of $146.9 \mathrm{~mm}$, which has an estimated return period of approximately 290 years. Thus, conditions for the development of extreme hydro-meteorological events were already in place before the development of Xynthia.

To analyze the origins of air masses involved in the cyclone development in more detail, a Lagrangian backward trajectory analysis (Noone and Simmonds, 1999) is performed. Trajectories starting at 00 UTC 27 February are calculated 72 hours backwards from six different tropospheric pressure levels inside the warm sector of Xynthia, which was located at this time southwest of the Portuguese coast (Fig 3(a)). The warm sector is characterized by an area of warm and moist air, indicated by high values of lower-level equivalent potential temperatures $\left(\Theta_{e}\right)$. The air mass inside the warm sector of Xynthia is found to originate from areas with anomalously warm SSTs (Fig 3(a)). Boundary-layer air masses (up to $975 \mathrm{hPa}$ ) originate close to the West African coast, while mid-tropospheric air masses (400-600 hPa) originate from the central subtropical North Atlantic. The mid-tropospheric air masses originate close to the surface (beneath $900 \mathrm{hPa}$ ) and are rapidly lifted over the last 36 hours of the analysis (Fig. 3(b)). The specific humidity of these air masses decreases significantly during the lifting (Fig. 3(c)). Hence, moist air from low levels is transported to higher altitudes within the cyclone while undergoing condensation and releasing latent heat. Due to their rapid ascent, these air masses can be assigned to the warm conveyor belt of the storm, where strong lifting of air masses is typical (e.g. Carlson, 1991). For the boundary-layer air masses, which underwent only a slight descent during the last 24 hours of the trajectory 
analysis (Fig. 3(b)), a strong increase of specific humidity can be observed before reaching the cyclone core (Fig. 3(c)), thus implying that humidity is gained by these air masses while flowing over warm ocean surfaces. These findings are consistent with results of Liberato et al. (2013), who used a more complex evaporation/precipitation Lagrangian method (Stohl et al., 1998) that is able to identify the evaporative sources associated with the development of Xynthia in the subtropical North Atlantic.

Atmospheric conditions at three different times during the phase of Xynthia's rapid intensification are presented in Fig. 4. At 00 UTC 26 February a long-wave trough at $300 \mathrm{hPa}$ is centred over the North Atlantic (Fig. 4(a)). A PV-streamer with values of more than 4 PVU is located within the axis of the trough; the tip of the PV-streamer is vertically aligned with the identified surface cyclone. The jet stream exhibits a split structure (Fig. 4(d)). At the exit region of the western branch of the jet stream, which is vertically aligned with the surface cyclone, strong upper-level divergence can be observed. Hence, upper-air conditions facilitate the early development of the cyclone. At lower levels $(850 \mathrm{hPa})$, the PV-distribution exhibits a local maximum in the vicinity of the cyclone, reaching almost 1PVU (Fig. 4(g)). Additionally, a weaker second low-level PV-maximum is located further downstream (cf. Rivière, 2012). A backwards vertical tilt between upper- and lower-level vorticity maxima is favourable for baroclinic development of the cyclone (e.g. Holton, 1979). The $\Theta_{e}$ field shows a strong horizontal gradient over central and eastern parts of the subtropical North Atlantic. At this stage, the cyclone is located on the southern edge of the frontal zone.

At 00 UTC 27 February, the upper-level trough with its embedded PV-streamer and the major jet structure have moved further eastward, with the cyclone still being located in the area of strong upper-level divergence between the two jet streaks (Figure 4(b) and 4(e)). Thus, perfect conditions for further deepening of the cyclone are provided (cf. Fig. 1(b)). 
Close to the centre of the cyclone, the two lower-tropospheric PV maxima merged to form an elongated coherent maximum, exceeding values of more than 2 PVU (Fig. 4(h)). The gradient of $\Theta_{e}$ has also sharpened in the vicinity of the cyclone. We hypothesize that this increase in PV can be at least partly attributed to diabatic processes like latent heat release through the condensation of lifted moist air. In this study the contribution of the anomalously high SSTs in the storm's genesis region to this diabatic PV component is determined.

At 00 UTC 28 February, the cyclone has reached its maximum intensity (see Fig. 1(b)). The upper-level trough has considerably weakened (Fig. 4(c)). The PV-streamer has moved further to the northeast and is located over the Bay of Biscay. Upper-level divergence still exhibits locally large values, while the eastern branch of the jet stream has weakened significantly (Fig. 4(f)). The cyclone core is now associated with a single contracted PV maximum exhibiting further enhanced values at $850 \mathrm{hPa}$ (Fig. 4(i)). Afterwards, the surface cyclone migrates further towards colder air masses and is consequently isolated from the warm and humid air masses, and thus from this energy reservoir.

\section{Numerical model studies}

\section{a) Validation of the CCLM control simulation}

To explicitly analyse the role of the anomalous SST and associated latent heat release for the development of Xynthia as represented in CCLM, the validation of the control experiment (CNTRL) is first required. The CNTRL experiment is forced with undisturbed initial conditions (including observed SSTs, see section 2), and is validated against ERA-Interim reanalysis, DWD analysis, and observations from the two synoptic stations Porto and Chassiron (for location see Fig. 5(a)). In general, the simulated track of Xynthia and the 
temporal evolution of the core pressure in CNTRL are in good agreement with ERA-interim (Fig. 5). The core pressure is slightly deeper in the CNTRL simulation than in the reanalysis during the regarded period. The lowest pressure is analysed from the reanalysis at 28 February 00 UTC $(969.2 \mathrm{hPa})$, located over the Bay of Biscay, while the core pressure in the CNTRL simulation occurs two hours earlier $(966.7 \mathrm{hPa})$. The simulated cyclone track is slightly shifted southwards compared to ERA-Interim. The simulated wind signature (maximum wind speed per grid point during the whole episode) exhibits highest wind gusts south of the track with a maximum speed of $45.8 \mathrm{~m} \mathrm{~s}^{-1}$ west of the Portuguese coast (Fig. $5(\mathrm{a}))$.

The $300 \mathrm{hPa}$ geopotential height, upper-tropospheric wind speed and direction as simulated by CNTRL are quite similar to DWD analysis, which is shown for the 27 February 12 UTC (Fig. 6). As CCLM is forced by ERA-Interim, we chose DWD analysis for comparison to have an independent dataset to evaluate the model performance. In both the DWD analysis and CNTRL, a distinct trough over the central and eastern North Atlantic and a small ridge over the western Mediterranean can be observed. The strong geopotential height gradient near the western coast of Spain and super-geostrophic conditions over southern France lead to high wind speeds of up to $100 \mathrm{kn}$ over south-western Europe and are simulated quite realistically by CNTRL. The simulated upper-level jet stream (Fig 6(b)) shows a split structure with branches located over central Europe and east of the Iberian coast. This is similar to the upper-level jet stream structures observed in the reanalysis data (cf. Fig. 4 and section 3).

Observed meteorological parameters at two synoptic stations, Chassiron and Porto, are compared to CNTRL at the respective nearest model grid point (Fig. 7). Chassiron is located on the island of Oleron just offshore the French Atlantic coast, where some of the most severe damage was reported (Lumbroso and Vinet, 2011). Porto is located at the Portuguese 
coast just south of the area where Xynthia first hit Iberia. Simulated time series of mean sea level pressure (MSLP) and wind speed at $10 \mathrm{~m}$ are in good agreement with observations for both stations with respect to their temporal evolution as well as their magnitude (Fig. 7(b) and 7(d)). Correlation coefficients between simulated and observed time series for Chassiron are 0.89 for wind speed and 0.98 for MSLP; for Porto the same coefficients are 0.76 and 0.99 , respectively. The rapid decrease of MSLP to a minimum pressure of approximately $975 \mathrm{hPa}$ in the early afternoon of 27 February for Porto and around midnight on 28 February for Chassiron is well reproduced by CCLM. On the other hand, the strong pressure increase at Chassiron after Xynthia has passed is simulated too early by CNTRL. As a consequence, simulated wind speeds reach their maximum an hour prior to the observations at Chassiron (Fig. 7(b)). Observed and simulated air and dew point temperatures have similar time series for both synoptic stations (Fig. 7(a) and 7(c)). A sharp increase of air and dew point temperatures can be observed at both stations as the storm passes (before and after noon on 27 February at Porto and Chassiron respectively). This strong increase is due to the passing of the warm sector of the cyclone over the respective stations and is simulated quite realistically by CNTRL.

We conclude that CNTRL reproduces the fundamental meteorological parameters of the reanalysis and observational data sets realistically. Therefore, the CCLM seems to be appropriate for the simulation of a windstorm like Xynthia. The sensitivity experiments are presented in the following subsection.

\section{b) Results of the sensitivity experiments}

The sensitivity experiments are analysed to quantify the role of the SST and associated latent heat release in the development of Xynthia. The main differences between the various 
sensitivity studies and CNTRL are modified latent heat fluxes between the surface and the atmosphere (see section 2). Fig. 8 depicts latent heat fluxes for CNTRL (Fig. 8(a)) and the sensitivity experiments TS1, TS2, TS3, SF5 and SF10 (Fig. 8(b)-(f)) averaged over the 48h period from 00 UTC 26 February 2010 to 00 UTC 28 February 2010. As can be seen, the decrease of simulated latent heat flux is stronger in the sensitivity experiments in which the boundary layer roughness for heat is increased (SF5 and SF10), than in those with reduced SST (TS1, TS2, TS3).

The cyclone tracks and the temporal evolution of the core pressure as simulated by TS1, TS3, SF5, and SF10 compared to results from CNTRL are shown in Fig. 9(a). During the entire period the core pressure of TS1 is above the core pressure of CNTRL, with a difference of minimum core pressure of $4.3 \mathrm{hPa}$. This effect is strengthened in TS3, where the minimum core pressure difference is $8.7 \mathrm{hPa}$ above CNTRL. Additionally, the absolute minimum core pressure is reached with a retardation of nine hours in TS3 compared to CNTRL. The results of TS2 are within the range of the results of TS1 and TS3 (not shown). For all sensitivity experiments, cyclone tracks and 6-hourly positions are quite similar to CNTRL (Fig. 9(b)). These results suggest that decreasing the initial SST has only a small impact on the resulting cyclone track but a recognizable influence on the core pressure development. This assessment is strengthened by the results of the SF5 and SF10 experiments, which also show a clear reduction of storm intensity with minimal variations of the cyclone track compared to CNTRL. The resulting difference of minimum core pressure is $5.8 \mathrm{hPa}$ (for SF5) and $8.0 \mathrm{hPa}$ (for SF10), respectively. On 27 February 22UTC, when the core pressure in CNTRL reaches its absolute minimum, the deviations for the sensitivity experiment range between $5.9 \mathrm{hPa}$ (TS1) and $10.3 \mathrm{hPa}(\mathrm{TS} 3)$.

To further clarify the role of latent heat release on the development of Xynthia, the MSLP, low-level $\Theta_{e}$ and PV distributions simulated by TS3 and SF10 are compared to CNTRL (Fig. 
10). For CNTRL a band of high $\Theta_{e^{-}}$values (vertically averaged between 900 and $950 \mathrm{hPa}$ ), reaching from the eastern subtropical North Atlantic along the northwest African shoreline towards the cyclone centre, is obvious at 27 February 12 UTC (Fig. 10(a)). This indicates the availability of warm moist air masses, which on lifting can release latent heat and thus contribute to the further intensification of Xynthia. Compared to CNTRL, both TS3 (Fig. 10(b)) and SF10 (Fig. 10(c)) clearly show decreased and westward shifted low-level $\Theta_{e}$ over the eastern North Atlantic. As PV is conserved under adiabatic frictionless conditions, positive PV-anomalies in the lower troposphere are likely to be (at least partly) attributable to diabatic processes. For CNTRL, high values of low-level PV (vertically averaged between 750 and $900 \mathrm{hPa}$ ) along the Portuguese coast are simulated (Fig. 10(d)). In TS3 (Fig. 10(e)) and SF10 (Fig. 10(f)), simulated low-level PV is weaker (up to 2PVU) in the vicinity of the cyclone compared to CNTRL. The association with reduced low-level $\Theta_{e}$ implies that the reduction is due to weaker diabatic processes in the sensitivity experiments.

Finally, the effect of the reduced surface latent heat fluxes on cyclone-related precipitation is analysed. Heavy 12-hourly accumulated precipitation of up to $69.6 \mathrm{~kg} \mathrm{~m}^{-2}$ along the cyclone track (with large both resolved and parameterized components) is simulated by CNTRL (Fig. $10(\mathrm{~g}))$; the mean precipitation is $10.47 \mathrm{~kg} \mathrm{~m}^{-2}$ per grid point for a representative subdomain (see dashed box in Fig 10(g)-(i)). Less accumulated precipitation, peaking at $64.1 \mathrm{~kg} \mathrm{~m}^{-2}$ and with an average of $9.4 \mathrm{~kg} \mathrm{~m}^{-2}$ per grid point, can be observed for TS3 (Fig. 10(h)). The decrease of accumulated precipitation is even stronger for SF10, with accumulated precipitation of less than $53.1 \mathrm{~kg} \mathrm{~m}^{-2}$ (average of $9.1 \mathrm{~kg} \mathrm{~m}^{-2}$ per grid point) for the entire area (Fig. 10(i)). Weaker precipitation can be attributed to a) reduced available moisture from the sea due to reduced surface fluxes of latent heat, and/or b) weaker lifting during the deepening phase of the cyclone.

This article is protected by copyright. All rights reserved. 
We conclude that the artificial reduction of surface latent heat fluxes inhibits the intensification of the cyclone, the development of PV through diabatic processes, and cyclone precipitation.

\section{c) Vertical perspective on the PV development}

Analysing the vertical distribution of PV-anomalies and diagnosis of diabatic heating rate (DHR, section 2) provides more profound insights into the role of latent heat release on the intensification phase of Xynthia. Here, we consider vertical cross sections of PV and DHR centred over the surface cyclone and averaged over $4^{\circ}$ in the east-west direction and $10^{\circ}$ in the north-south direction. Fig. 11(a)-(d) show the south-north orientated vertical sections of PV and relative humidity $(\mathrm{RH})$ for CNTRL for different stages of development. The geographical locations of the cross sections are shown in Fig 5(a). At 26 February 12 UTC, high PV-values can be observed in the upper troposphere with maximum values at the tropopause level (Fig 11(a)). This is consistent with the identified upper-level PV-streamer as shown in Fig. 4(a)-(c). A secondary simulated PV maximum can be seen at mid-tropospheric levels which may be attributed to diabatic heating processes within the warm conveyor belt. Hence, crucial atmospheric conditions for a rapid cyclone development are present. Further, north of the surface cyclone centre moist air masses with $\mathrm{RH}$ of more than $80 \%$ reach up above $500 \mathrm{hPa}$, reflecting the upward transport of warm and moist air within the warm conveyor belt of the cyclone. Twelve hours later, a distinct PV-tower with two regions of maximum PV extends from the surface to the upper troposphere right above surface cyclone (Fig. 11(b)). The PV-tower is the result of the merging of diabatically produced PV and upper-level PV. Additionally, the region of moist air north of the cyclone has further enlarged which is an indicator of the ongoing uplifting of humid air masses on 27 February 00 UTC. Above this region, lower values of PV occur as the result of reduced PV above the area of strongest latent heat release. South of the cyclone a region of dry midtropospheric air 
develops, associated with the dry intrusion (Browning, 1997). On 27 February 12 UTC, the low and mid troposphere above the surface cyclone is still characterised by an amplified PVtower (Fig. 11(c)). While moist air is still advected to upper levels within the warm conveyor belt of the cyclone, the dry intrusion south of the surface cyclone extends downwards to $700 \mathrm{hPa}$. At peak intensity of the storm, 28 February $00 \mathrm{UTC}$, the PV-tower extends throughout the whole troposphere. Values of up to 3 PVU are visible at lower levels, consistent with diabatic processes taking place here. To the north, moist air is still reaching to higher levels, while the dry intrusion to the south manifests itself at mid-tropospheric levels.

The impact of diabatic processes on the PV structure of the storm is demonstrated by horizontally averaging PV over a $4^{\circ} \times 4^{\circ}$ box centred on the surface cyclone in the CNTRL and the sensitivity experiments TS3 and SF10 (Fig. 11(e)-(h)). The diagnoses of DHR confirm the influence of diabatic processes on the development of the storm. Strong DHR occurs within the corresponding air column at lower and mid-tropospheric levels during the deepening phase of the storm. While on 26 February 12 UTC the vertical distribution of PV is very similar in the three simulations (Fig. 11(e)), PV is reduced in both sensitivity experiments in the lower troposphere at later times (Fig. 11(f)-(h)). A decrease of PV of up to 0.9 PVU can be seen for 27 February 12 UTC (Fig. 11(g)). This coincides with a reduction in DHR of $0.5 \mathrm{~K} \mathrm{~h}^{-1}$ for TS3 and SF10, respectively. At the same time, upper-level PV values $(300-500 \mathrm{hPa})$ in the sensitivity experiments are enhanced in relation to CNTRL. The enhanced PV at 500hPa in TS3, and more clearly in SF10, is related to the reduced DHR just below $500 \mathrm{hPa}$. The overall weakened negative vertical gradient in $\mathrm{PV}$ in the sensitivity experiments can be attributed to the weaker DHR at mid-tropospheric levels. On 28 February 00 UTC (Fig. 11(h)) it is noticeable that DHR at lower levels has generally reduced by approximately $2 \mathrm{~K} \mathrm{~h}^{-1}$ since 27 February $12 \mathrm{UTC}$ while at upper levels only the sensitivity experiments show a marked reduction of the DHR. In particular the reduction of DHR at 
lower levels implies that the peak storm intensity has been reached (cf. Fig.9). To summarize, these results again clearly indicate the important role of moisture processes in the cyclogenesis of Xynthia and their contribution to the weaker intensification of the storm in the TS and SF experiments (cf. Fig. 9(a)).

\section{Summary and Conclusion}

The role of the anomalously high SST and associated latent heat release in the development of the exceptional windstorm Xynthia in early 2010 has been analysed. The record breaking negative phase of the NAO during the winter 2009/2010 was associated with a southward shift of the polar jet stream. These conditions favoured the development of Xynthia around $30^{\circ} \mathrm{N}$ near an area with anomalously warm SSTs even for the subtropical North Atlantic. The occurrence of an upper-level PV-streamer, a split jet stream associated with strong divergence and enhanced baroclinicity further contributed to the intensification of Xynthia. Results of two different sets of sensitivity experiments with the CCLM demonstrate the importance of the enhanced SST and surface latent heat fluxes to the development of Xynthia.

Our findings regarding the main atmospheric driving factors during the intensification of Xynthia are in agreement with a variety of studies on extratropical cyclones. In more detail, these driving factors are the existence of a strong jet stream with accompanied horizontal divergence, enhanced baroclinicity and availability of latent heat energy. Further, the importance of a split jet structure analysed during the stage of rapid intensification has already been ascertained for recent windstorms such as Lothar, Kyrill and Klaus (Wernli et al., 2002; Liberato et al., 2011; Fink et al., 2012). In general, a prevailing negative NAO reduces the total number of extreme cyclones over the North Atlantic, but increases the 
number of systems travelling towards Southwestern Europe (e.g. Raible, 2007; Pinto et al., 2009). Thus, Xynthia may be seen as exemplary case study for extreme cyclogenesis over the subtropical Eastern North Atlantic.

The quantification of dry baroclinic versus moist diabatic processes (e.g. Fink et al., 2012) reveal the importance of diabatic processes during the intensification of windstorms like Xynthia. Here, this is estimated by considering regional model simulations with perturbed physics. Langland et al. (1996) showed that the intensification of an idealized extratropical cyclone was sensitive to increasing the transfer coefficient of the surface latent heat flux. In our sensitivity experiments, the surface heat fluxes were artificially reduced by increasing the laminar boundary roughness length for heat (rlam_heat; cf. Bellprat et al. 2012) or reducing the SST. The results of our sensitivity studies with the CCLM confirm the importance of diabatic processes for Xynthia, as these experiments show a weaker and retarded intensification of the storm. The contribution of enhanced SSTs to the intensification of extratropical storms has been discussed by several modelling studies e.g. for storm Lothar (Wernli et al., 2002). Our results are also in accordance with other studies addressing the influence of SST anomalies on the development of storms. For instance, Booth et al. (2012) analyzed the sensitivity of midlatitude storm intensification to perturbations in the SST near the Gulf Stream revealing enhanced SSTs lead to stronger storms. The same relationship had also been found by Giordani and Caniaux (2001).

The formation of a PV-tower is a typical characteristic of strong extratropical cyclones (e.g. Wernli, 2002; Campa and Wernli, 2012). As Xynthia intensifies, a strong PV-tower develops above the surface cyclone within our control simulation. Likewise, we are able to show the existence of an upper-level stratospheric intrusion (PV-streamer) that merges with a diabatically produced PV-anomaly at low and midlevels. This interaction is typical for east Atlantic cyclones, where upper-level forcing and mid-level latent heating are of equal 
importance (cf. Dacre and Gray, 2013). The results of the DHR diagnosis and the decrease of the PV-tower in our sensitivity experiments demonstrate the importance of available lowlevel moisture for the diabatic processes during the intensification of the storm. The large values of low-level PV can be attributed to high potential temperatures at the surface (Campa and Wernli, 2012). Sensitivity studies with reduced SST or with increased laminar boundary roughness for heat showed a reduction of surface latent heat fluxes, inducing both a weaker and generally retarded development of the cyclone, and a weakening of the PV-tower, particularly at lower levels (cf. Fig. 11(f) and 11(g)). This fact along with the overall reduced DHR in the sensitivity experiments corroborates our hypothesis that anomalously high values of SST over the subtropical North Atlantic and the associated latent heat release were instrumental for the development of Xynthia.

A pertinent scientific question is the potential impact of increasing greenhouse gas forcing on storms undergoing explosive development on the southern edge of the North Atlantic storm track (around $35^{\circ} \mathrm{N}-45^{\circ} \mathrm{N}$ ) like Klaus (Liberato et al., 2011) and Xynthia. For example, Pinto et al. (2009) argued that the conditions for such intense developments close to Europe may be more favourable under future climate conditions, and suggested that the importance of diabatic processes during the intensification of extreme cyclones may significantly increase. Further, Bengtsson et al. (2009) estimated that the most prominent change in storm characteristics under future climate conditions is a significant increase in total precipitation. Based on these and other studies, we suggest that storms like Xynthia may occur more frequently under future climate conditions, increasing the windstorm risk for South-western Europe.

This article is protected by copyright. All rights reserved. 
Acknowledgments: We thank the European Centre for Medium-Range Weather Forecasts (ECMWF, UK) for providing the ERA-Interim reanalysis data. We thank the German Climate Computer Centre (DKRZ, Hamburg) for computer and storage resources within the context of DKRZ project ANDIVA (Nr. 105). We thank Andreas H. Fink (Univ. Cologne) for discussions.

\section{Literature}

Ahmadi-Givi, F., Graig, G. C. and Plant, R. S. 2004, The dynamics of a midlatitude cyclone with very strong latent-heat release. Q. J. R. Meteorol. Soc., 130, 295-323. doi: 10.1256/qj.02.226

Baehr, C., Pouponneau, B., Ayrault, F., and Joly, A. 1999. Dynamical characterization of the FASTEX cyclogenesis cases. Quart. J. R. Meteorol. Soc., 125, 3469-3494.

Barras, V., and Simmonds, I. 2009. Observation and modeling of stable water isotopes as diagnostics of rainfall dynamics over southeastern Australia. J. Geophys. Res., 114, D23308.

Bedacht, E., and Hofherr, T. 2011. Wintersturm Xynthia in Südwesteuropa und Deutschland. Munich Re Topics Geo 2010, 18-21 (in German language).

Bellprat, O., Kotlarski, S., Lüthi, D., and Schär, C. 2012. Exploring Perturbed Physics Ensembles in a Regional Climate Model. J. Climate., 25, 4582-4599.

Bengtsson L, Hodges KI, Keenlyside N. 2009. Will extratropical storms intensify in a warmer climate? J. Climate, 22, 2276-2301.

Berrisford, P. 1988. 'Potential vorticity in extratropical cyclones'. PhD thesis. University of Reading, UK.

Booth, J. F., Thompson, L., Patoux, J., and Kelly, K. A. 2012: Sensitivity of Midlatitude Storm Intensification to Perturbations in the Sea Surface Temperature near the Gulf Stream. Mon. Weather Rev., 140, 1241-1256.

Born, K., Ludwig, P., and Pinto, J.G. 2012. Wind gust estimation for mid-European winter storms: Towards a probabilistic view. Tellus A, 64, 17471.

Browning, K.A. 1997. The dry intrusion perspective of extra-tropical cyclone development. Meteorological Applications, 4, 317-324.

This article is protected by copyright. All rights reserved. 
Campa, J., and Wernli, H. 2012. A PV perspective on the vertical structure of mature midlatitude cyclones in the Northern Hemisphere. J. Atmos. Sci., 69, 725-740.

Carlson, T.N. 1991. Mid-latitude weather systems. Harper Collins, London, pp 507

Chang, C.B., Perkey, D.J., and Kreitzberg, C.W. 1982. A numerical case study of the effects of latent heating on a developing wave cyclone. J. Atmos. Sci., 39, 1555-1570.

Chagnon, J. M., S. L. Gray, and J. Methven (2012), Diabatic processes modifying potential vorticity in a North Atlantic cyclone. Quart. J. R. Meteorol. Soc., 139, 1270 -1282.

Dacre, H. F., and S. L. Gray, 2009: The Spatial Distribution and Evolution Characteristics of North Atlantic Cyclones. Mon. Weather Rev., 137, 99-115.

Dacre, H. F., and S. L. Gray 2013. Quantifying the climatological relationship between extratropical cyclone intensityand atmospheric precursors, Geophys. Res. Lett., 40, 2322-2327.

Danard, M.B. 1964. On the influence of released latent heat on cyclone development. J. Appl. Meteor., 3, 27-37.

Davis, C. A. and Emanuel, K. A. 1991 Potential vorticity diagnostics of cyclogenesis. Mon. Weather Rev., 119, 1929-1953

Dee, D. P., and 35 co-authors. 2011. The ERA-Interim reanalysis: configuration and performance of the data assimilation system. Quart. J. R. Meteorol. Soc., 137, 553-597.

Deveson, A.C.L., Browning, K.A. and Hewson, T.D. 2002: A classification of FASTEX cyclones using a height-attributable quasi-geostrophic vertical-motion diagnostic. Quart. J. R. Meteorol. Soc., 128, 93-117.

Dickinson, M.J., Bosart, L.F., Bracken, W.E., Hakim, G.J., Schultz, D.M., Bedrick, M.A., Tyle, K.R. 1997. The March 1993 Superstorm Cyclogenesis: Incipient Phase Synoptic- and Convective-Scale Flow Interaction and Model Performance. Mon. Weather Rev., 125, 3041-3072.

Etienne, C., Goyette, S., and Kuszli, C.-A. 2013: Numerical investigations of extreme winds over Switzerland during 1990-2010 winter storms with the Canadian Regional Climate Model. Theor. Appl. Climatol., 113, 529-547.

Fink, A.H., Pohle, S., Pinto, J.G., and Knippertz, P. 2012. Diagnosing the influence of diabatic processes on the explosive deepening of extratropical cyclones. Geophys. Res. Lett., 39, L07803, doi:10.1029/2012GL051025.

This article is protected by copyright. All rights reserved. 
Fragoso, M., Trigo, R.M., Pinto, J.G., Lopes, S., Lopes, A., Ulbrich, S., and Magro, C. 2012. The 20 February 2010 Madeira Flash-floods: Atmospheric controls and extreme rainfall assessment. Nat. Hazards Earth Syst. Sci., 12, 715-730.

Giordani, H., and Caniaux, G. 2001: Sensitivity of Cyclogenesis to Sea Surface Temperature in the Northwestern Atlantic. Mon. Weather Rev., 129, 1273-1295.

Grams, C. M., Wernli, H., Böttcher, M., Čampa, J., Corsmeier, U., Jones, S. C., Keller, J. H., Lenz, C.-J. and Wiegand, L. 2011. The key role of diabatic processes in modifying the upper-tropospheric wave guide: a North Atlantic case-study. Quart. J. R. Meteorol. Soc., 137, 2174-2193.

Gray, S.L., and Dacre H.F. 2006. Classifying dynamical forcing mechanisms using a climatology of extratropical cyclones. Quart. J. Roy. Meteor. Soc., 132, 1119-1137.

Holton, J.R. 1979: An introduction to dynamic meteorology. 2nd ed. Academic Press, New York. pp. 216-227.

Hoskins, B., McIntyre, M.E., and Robertson, A.W. 1985. On the use and significance of isentropic potential vorticity maps. Quart. J. Roy. Meteorol. Soc., 111, 877-946.

Hoskins, B.J. 1990. Theory of extratropical cyclones. Pp. 63-80 in Extratropical cyclones. The Erik Palmen Memorial Volume. Eds. C. Newton and E. O. Holopainen. American Meteorological Society, Boston.

Hoskins, B.J., and Valdes, P.J. 1990. On the existence of storm-tracks. J. Atmos. Sci., 47, 1854 - 1864.

Hoskins, B.J. and Hodges, K.I. (2002) New perspectives on the Northern Hemisphere winter storm tracks. J. Atmos. Sci., 59, 1041-1061.

Joos, H., and Wernli, H. 2012. Influence of microphysical processes on the potential vorticity development in a warm conveyor belt: a case study with the limited area model COSMO. Quart. J. R. Meteorol. Soc., 138, 407-418.

Lamb, H.H. 1991. Historic storms of the North Sea, British Isles, and Northwest Europe. Cambridge University Press, Cambridge, 204pp.

Langland, R.H., Elsberry, R.L. and Errico, R.M. 1996. Adjoint sensitivity of an idealized extratropical cyclone with moist physical processes. Quart. J. R. Meteorol. Soc., 122, 1891-1920.

Liberato, M.L.R., Pinto, J.G., Trigo, I.F. and Trigo, R.M. 2011. Klaus - an exceptional winter storm over northern Iberia and southern France. Weather, 66, 330-334.

This article is protected by copyright. All rights reserved. 
Liberato, M.L.R., Pinto, J.G., Trigo, R.M., Ludwig, P., Ordóñez, P., Yuen, D., and Trigo, I.F. 2013. Explosive development of winter storm Xynthia over the southeastern North Atlantic. Nat. Hazards Earth Syst. Sci., in press.

Lumbroso, D.M., and Vinet, F. 2011. A comparison of the causes, effects and aftermaths of the coastal flooding of England in 1953 and France in 2010. Nat. Hazards Earth Syst. Sci., 11, 23212333.

Massacand, A.C., Wernli, H., and Davies, H.C. 1998. Heavy precipitation on the Alpine southside: an upper-level precursor. Geophys. Res. Lett., 25, 1435-1438.

Massacand, A.C., Wernli, H., and Davies, H.C. 2001. Infuence of upstream diabatic heating upon an Alpine event of heavy precipitation. Mon. Weather Rev., 129, 2822-2828.

Noone, D., and Simmonds, I. 1999. A three-dimensional spherical trajectory algorithm. Research Activities in Atmospheric and Oceanic Modelling, Report No. 28, WMO/TD-No. 942. H. Ritchie, Ed., World Meteorological Organization, 3.26-3.27.

Osborn, T.J. 2011. Winter 2009/10 temperatures and a record-breaking North Atlantic Oscillation index. Weather, 66, 19-21.

Piaget, N. 2011. Genesis of winter storm Xynthia. Master Thesis, IACETH, Zürich.

Pinto, J.G., Zacharias, S., Fink, A.H., Leckebusch, G.C., and Ulbrich, U. 2009. Factors contributing to the development of extreme North Atlantic cyclones and their relationship with the NAO. Clim. Dyn., 32, 711-737.

Plant, R.S., Craig, G.C. and Gray, S.L. 2003. On a threefold classification of extratropical cyclogenesis. Quart.J. R. Meteorol. Soc., 129, 2989-3012.

Pomroy H.R., and Thorpe A.J. 2000. The evolution and dynamical role of reduced upper-tropospheric potential vorticity in intensive observing period one of FASTEX. Mon. Weather Rev., 128, 18171834.

Raible, C.C. 2007. On the relation between extremes of midlatitude cyclones and the atmospheric circulation using ERA40. Geophys. Res. Lett., 34, L07703. doi:10.1029/2006GL029084

Reed, R. J., Stoelinga, M.T., and Kuo, Y.-H. 1992. A model-aided study of the origin and evolution of the anomalously high potential vorticity in the inner region of a rapidly deepening marine cyclone. Mon. Weather Rev., 120, 893-913.

This article is protected by copyright. All rights reserved. 
Rivière, G., Arbogast, P., Lapeyre, G., and Maynard, K. 2012: A potential vorticity perspective on the motion of a mid-latitude winter storm. Geophys. Res. Lett., 39, L12808, doi:10.1029/2012GL052440.

Robertson, F.R., and Smith, P.J. 1983. The impact of model moist processes on the energetics of extratropical cyclones. Mon. Weather Rev., 111, 723-744.

Rockel, B., Will, A. and Hense, A. (eds.) 2008. Special issue: regional climate modelling with COSMO-CLM (CCLM). Meteorol. Z., 17, 347-348.

Santos, J.A., Woollings, T., Pinto, J.G. 2013. Are the winters 2010 and 2012 archetypes exhibiting extreme opposite behavior of the North Atlantic jet stream? Mon. Weather Rev., in press, doi:10.1175/MWR-D-13-00024.1.

Snyder, C. and Lindzen R.S. 1991. Quasi-geostrophic Wave-CISK in an unbounded baroclinic shear. J. Atmos. Sci., 48, 76-86.

Stohl, A., Hittenberger, M. and Wotawa, G. 1998. Validation of the Lagrangian particle dispersion model FLEXPART against large scale tracer experiment data. Atmos. Environm., 32, 4245-4264.

SwissRe 2008. Natural catastrophes and man-made disasters in 2007: high losses in Europe. Sigma, Nr. 1/2008. Swiss Re publishing. Available at www.swissre.com/sigma/

Trigo, I.F. 2006. Climatology and interannual variability of storm-tracks in the Euro-Atlantic sector: a comparison between ERA-40 and NCEP/NCAR reanalyses. Clim. Dyn., 26, 127-143.

Uccellini, L.W., and Johnson, D.R. 1979. The coupling of upper and lower tropospheric jet streaks and implications for the development of severe convective storms. Mon. Weather Rev., 107, 682-703.

Uccelini, L.W. 1990. Process contributing to the rapid development of extratropical cyclones; in: Extratropical Cyclones, The Erik Palmen Memorial Volume, Ed. Chester Newton and Eero O Holopainen, p. 81 - 105, American Meteorological Society, Boston

von Storch, H, Langenberg H., and Feser, F. 2000: A Spectral Nudging Technique for Dynamical Downscaling Purposes. Mon. Weather Rev., 128, 3664-3673.

Wanner, H., Bronnimann, S., Casty, C., Gyalistras, D., Luterbacher, J., Schmutz, C., Stephenson, D.B., and Xoplaki, E. 2001. North Atlantic oscillation. Concepts and studies. Surv. Geophys., 22, $321-382$.

Wernli, H., Davies, H.C. 1997. A Lagrangian-based analysis of extratropical cyclones. I: The method and some applications. Quart. J. R. Meteorol. Soc., 123, 467-489.

This article is protected by copyright. All rights reserved. 
Wernli, H., Dirren, S., Liniger, M. A. and Zillig, M. 2002. Dynamical aspects of the life cycle of the winter storm 'Lothar' (24-26 December 1999). Quart. J. Roy. Meteorol. Soc., 128, 405-429.

Willison, J., Robinson, W., and Lackmann, G. 2013. The importance of resolving mesoscale latent heating in the North Atlantic stormtrack. J. Atmos. Sci., 70, 2234-2250.

Woollings, T., Hannachi, A., and Hoskins, B. 2010. Variability of the North Atlantic eddy-driven jet stream. Quart. J. Roy. Meteorol. Soc., 136, 856-868.

This article is protected by copyright. All rights reserved. 


\section{Figure Captions}

Figure 1. 6-hourly cyclone location (a) and core pressure evolution (b) for Xynthia derived from ERA-Interim data. Data ranges from 25 February 00 UTC until 02 March 00 UTC. (a): The CCLM model domain is marked by the black border. The model orography is shaded $[\mathrm{m}]$. The small black box at the south-western corner of the model domain delimits the region where SST is perturbed for sensitivity studies.

Figure 2. Long term average of SST over the North Atlantic basin for February (1980-2009) from ERA-Interim data (isolines with an interval of $2^{\circ} \mathrm{C}$ ) and SST anomalies for February 2010 (shaded). Areas with an anomaly more/less than twice the standard deviation are indicated with black dots. Cyclone track is included in grey.

Figure 3. (a) $\Theta_{e}$ distribution at $950 \mathrm{hPa}$ (green isolines with an interval of 10K), positive SST anomalies (shaded) and backward trajectories of airflows inside the warm sector of the cyclone. All trajectories start at 00UTC on 27 February and are calculated backwards for 72 hours. The colours of the trajectories indicate the starting height (cf. 3(b) for colour key). Area where SST is reduced in CCLM sensitivity studies is also included as black frame. (b) Pressure along the trajectories. (c) Specific humidity along the trajectories.

Figure 4. Synopsis of different meteorological parameters for three time steps during rapid intensification of Xynthia: left column 26 February 00 UTC; centre column 27 February 00 UTC; right column 28 February 00 UTC. (a)-(c): PV-distribution [PVU] (shaded) on the $320 \mathrm{~K}$ isentropic level and geopotential height at $300 \mathrm{hPa}$ (black isolines with an interval of 16 gpdm); (d)-(f): jet stream [kts] (isolines) and divergence $\left[10^{-5} \mathrm{~s}^{-1}\right]$ (shaded) at $300 \mathrm{hPa}$; (g)-(i): PV-distribution [PVU] (shaded) and equivalent potential temperature $\Theta_{e}[\mathrm{~K}]$ (contour lines, every $5 \mathrm{~K}$ ) at $850 \mathrm{hPa}$. Please note that (d)-(i) are zoomed to the dashed box as shown in (a)(c) for better representation of synoptic scale variables. In all panels the black squares mark the location of the surface cyclone.

Figure 5. Cyclone location (a) and core pressure evolution (b) of Xynthia as derived from ERA-Interim (dashed line with squares) and CNTRL (solid line with circles). First depicted point is at 26 February 00 UTC. Squares/circles are in 6 hourly intervals until 02 March 00 UTC. (a): Shaded areas show wind signature of the storm (maximum wind gust above 
$17.5 \mathrm{~m} \mathrm{~s}^{-1}$ at each grid point during the considered period). Uppercase letters ' $\mathrm{P}$ ' and ' $\mathrm{C}$ ' indicate the locations of the synoptic stations Porto and Chassiron for further comparisons. The four vertical lines along the track assign the positions of north-south cross sections shown in Figure 11.

Figure 6. (a) Analysis of geopotential height [gpdm] (contours every 8gpdm) and wind vectors by DWD at $300 \mathrm{hPa}$ on 27 February 12UTC; (b) as (a), but for CNTRL. Wind speeds higher than 60 knots are shaded in intervals of 10 knots for clarification of upper level jet stream conditions in CNTRL.

Figure 7. Time series for different meteorological parameters at two different locations for CNTRL (dashed line) and synoptic stations (solid line). (a): 2-metre temperature (black, $\left[{ }^{\circ} \mathrm{C}\right]$ ) and dew point temperature (grey, $\left[{ }^{\circ} \mathrm{C}\right]$ ) for CCLM grid point $164,134\left(1.20^{\circ} \mathrm{W}, 46.11^{\circ} \mathrm{N}\right)$ and synoptic station 07314 (Chassiron, $1.41^{\circ} \mathrm{W}, 46.05^{\circ} \mathrm{N}$ ). (b) as (a), but for 10 -metre wind speed (grey, [kn]) and mean sea level pressure (black, [hPa]). (c) as (a) but for CCLM grid point $140,111\left(8.55^{\circ} \mathrm{W}, 41.20^{\circ} \mathrm{N}\right)$ and synoptic station 08545 (Porto, $\left.8.68^{\circ} \mathrm{W}, 41.23^{\circ} \mathrm{N}\right)$. (d): as (c) but for 10-metre wind speed (grey, $[\mathrm{kn}]$ ) and mean sea level pressure (black, $[\mathrm{hPa}]$ ). For station locations please refer to Figure 5.

Figure 8. Averaged latent heat fluxes at sea surface (in $\mathrm{W} \mathrm{m}^{-2}$ ) for the period 26 February 2010, 00 UTC to 28 February 2010, 00 UTC. (a) Undisturbed control simulation, (b) sensitivity study TS1 with $1 \mathrm{~K}$ reduction of SST, (c) sensitivity study SF5 with rlam_heat=5, (d) sensitivity study TS2 with $2 \mathrm{~K}$ reduction of SST, (e) sensitivity study TS3 with $3 \mathrm{~K}$ reduction of SST and (f) sensitivity study SF10 with rlam_heat $=10$. For more details see text.

Figure 9. (a) Core pressure evolution and (b) cyclone locations for various sensitivity experiments. For better presentation of the results, only results for TS1 (black/plus symbol), TS3 (grey/circle), SF5 (stippled grey/asterisk) and SF10 (stippled black/square) are included. As reference, the core pressure evolution and location for the CNTRL (diamond symbols) are included.

Figure 10. Top row: MSLP (contour each $2.5 \mathrm{hPa}$ ) and vertically averaged $\Theta_{e}$ between 900hPa and 950hPa on 27 February 12UTC for (a) CNTRL, (b) TS3, and (c) SF10. Centre row: as (a) to (c), but for lower-tropospheric PV vertically averaged between $750 \mathrm{hPa}$ and 900hPa. (e) and (f) also show negative (positive) PV-differences of TS3-CNTRL and SF10- 
CNTRL contoured as thick (stippled) black lines respectively (contour each 1PVU). For (a)(f), black/white circles indicate corresponding cyclone position. Bottom row: as (a) to (c), but for 12-hour precipitation accumulation on 27 February between 00UTC and 12UTC. Comparative values for precipitation are calculated in the box marked by dashed line (see text for details).

Figure 11. (a)-(d): South-north orientated vertical sections of the PV distribution [PVU] at different time steps (for positions of cross sections see Figure 5). PV and relative humidity (stippled isoline: $20 \% \mathrm{RH}$; dotted area: RH > 80\%) for CNTRL at a) 26 February 12UTC, (b) 27 February 00UTC, (c) 27 February 12UTC and (d) 28 February 00UTC. The location of the surface low is indicated by ' $\mathrm{L}$ '. (e)-(h): Vertical distribution of horizontal averaged PV (left, [PVU]) and diabatic heating rate $\left(\dot{\theta}\right.$, right, $\left.\left[\mathrm{K} \mathrm{h}^{-1}\right]\right)$ over a $4^{\circ} \times 4^{\circ}$ box centred on the surface cyclone at different time steps for CNTRL (solid black line), TS3 (stippled grey line) and SF10 (stippled black line). Time steps in (e)-(h) according to (a)-(d).

This article is protected by copyright. All rights reserved. 


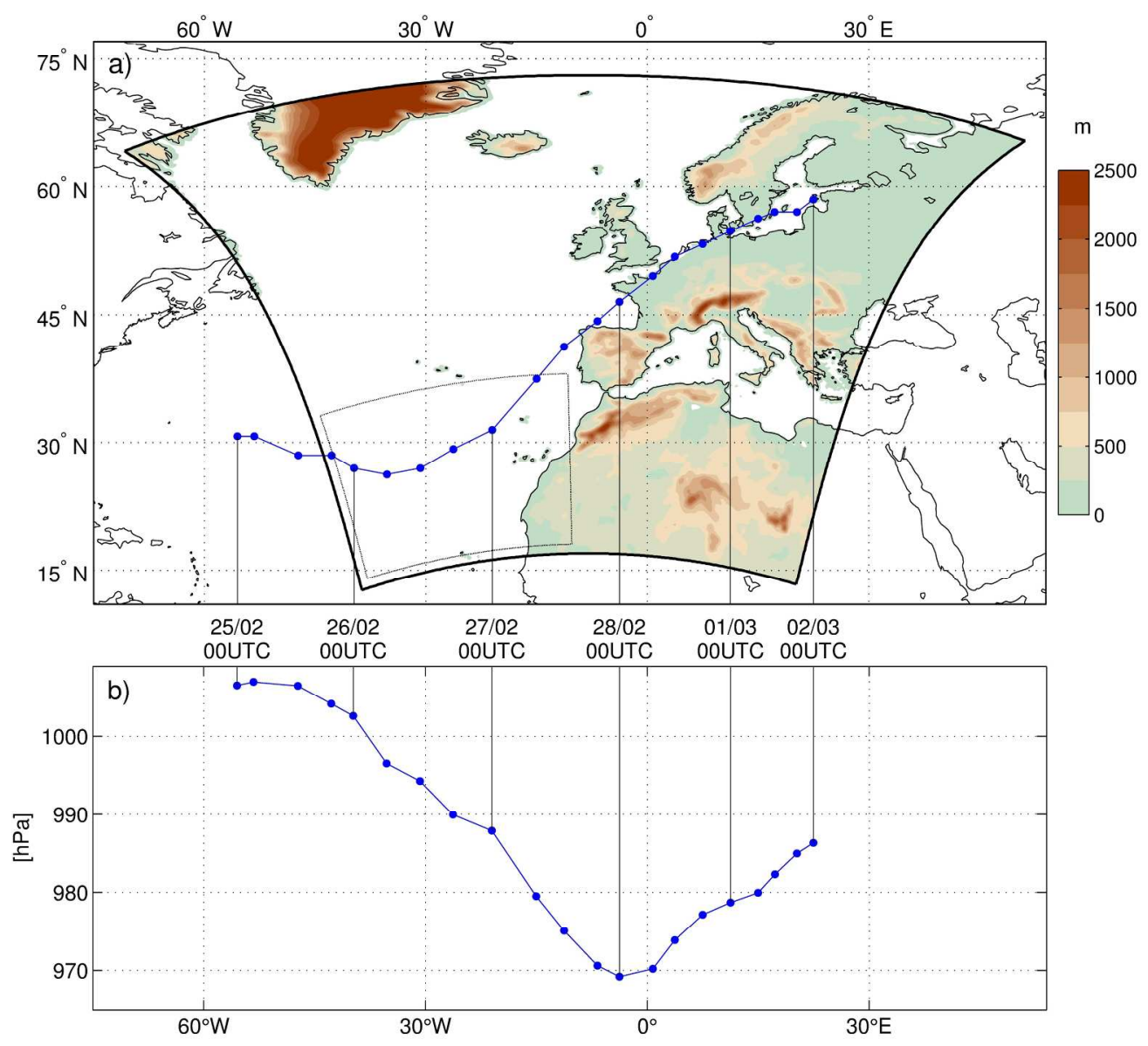

Figure 1. 6-hourly cyclone location (a) and core pressure evolution (b) for Xynthia derived from ERA-Interim data. Data ranges from 25 February 00 UTC until 02 March 00 UTC. (a): The CCLM model domain is marked by the black border. The model orography is shaded $[\mathrm{m}]$. The small black box at the south-western corner of the model domain delimits the region where SST is perturbed for sensitivity studies.

This article is protected by copyright. All rights reserved. 


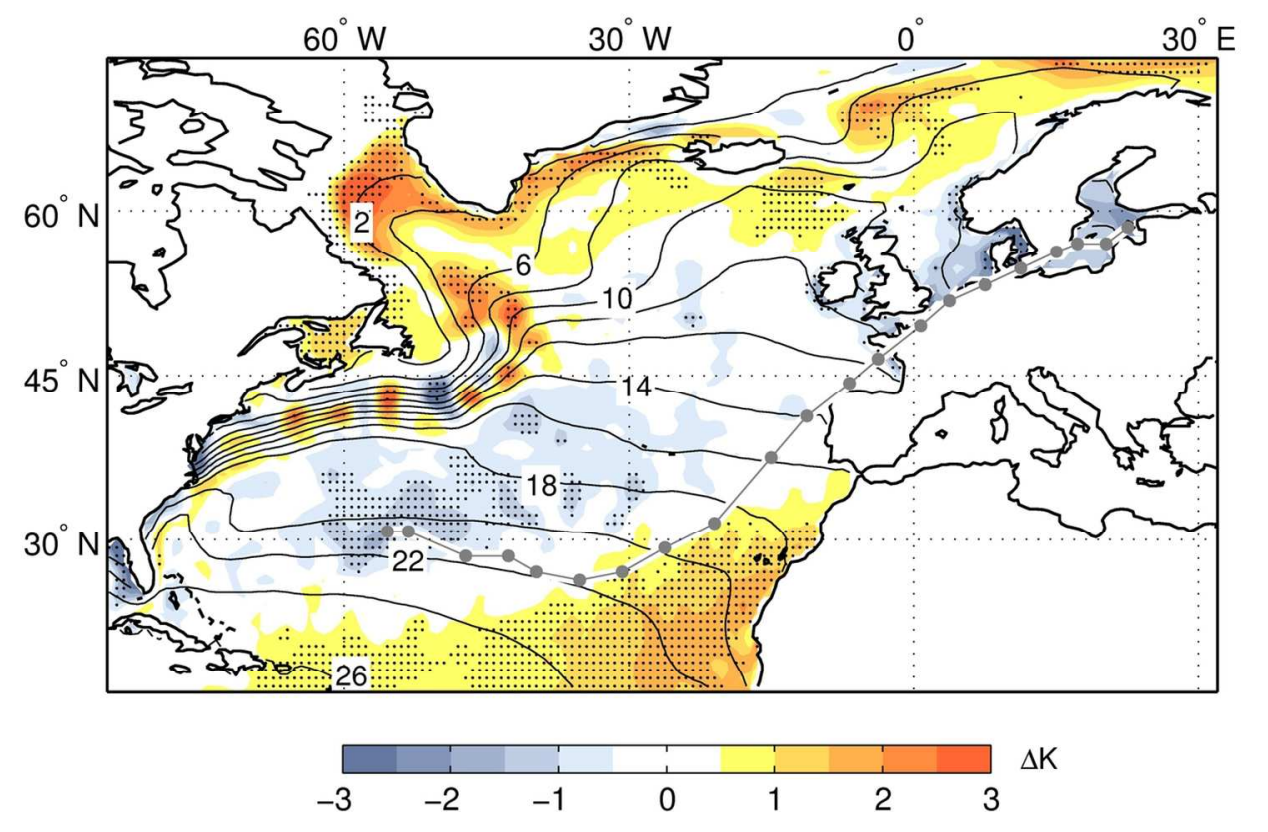

Figure 2. Long term average of SST over the North Atlantic basin for February (1980-2009) from ERAInterim data (isolines with an interval of $2^{\circ} \mathrm{C}$ ) and SST anomalies for February 2010 (shaded). Areas with an anomaly more/less than twice the standard deviation are indicated with black dots. Cyclone track is included in grey.

This article is protected by copyright. All rights reserved. 


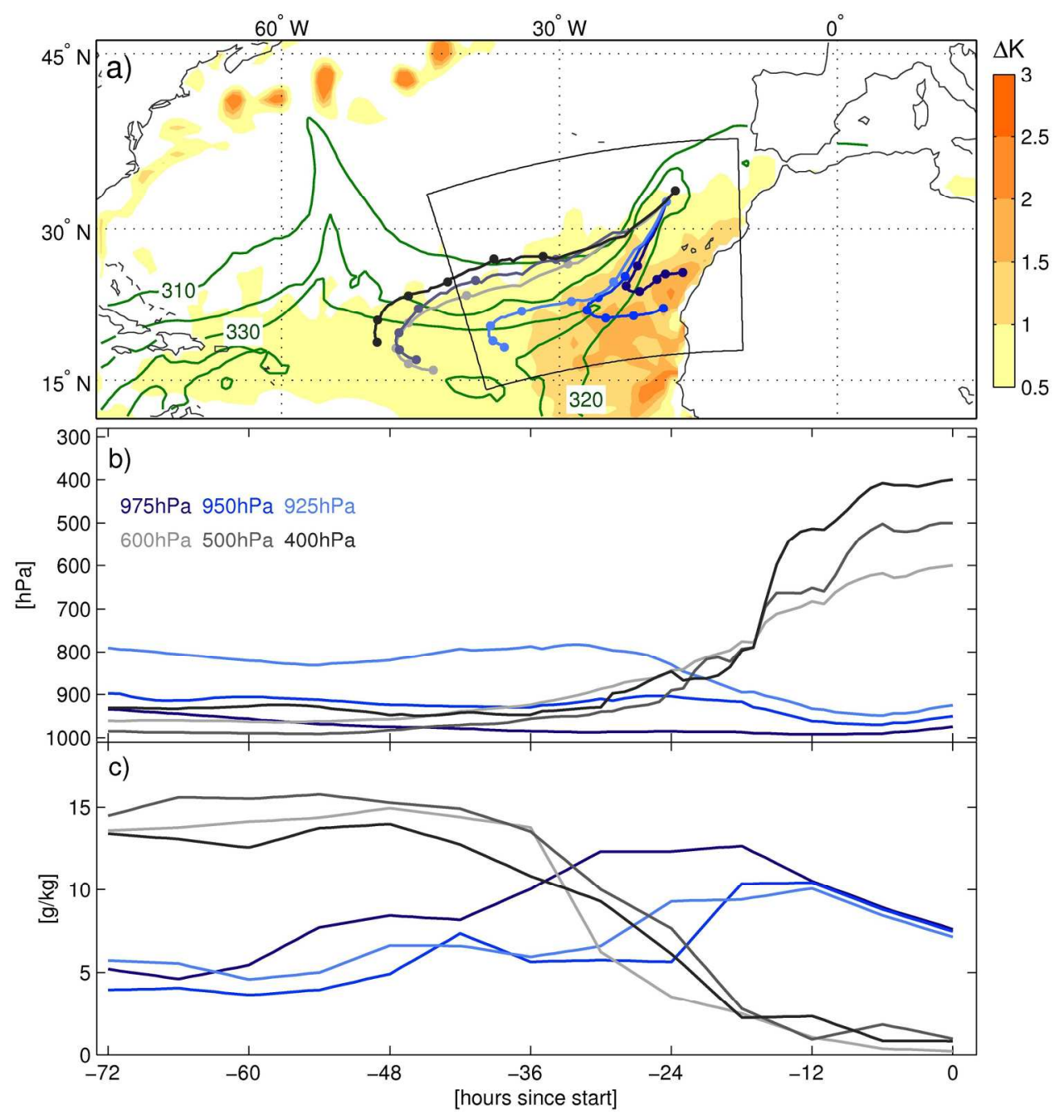

Figure 3. (a) $\Theta_{e}$ distribution at $950 \mathrm{hPa}$ (green isolines with an interval of $10 \mathrm{~K}$ ), positive SST anomalies (shaded) and backward trajectories of airflows inside the warm sector of the cyclone. All trajectories start at 00 UTC on 27 February and are calculated backwards for 72 hours. The colours of the trajectories indicate the starting height (cf. 3(b) for colour key). Area where SST is reduced in CCLM sensitivity studies is also included as black frame. (b) Pressure along the trajectories. (c) Specific humidity along the trajectories.

This article is protected by copyright. All rights reserved. 

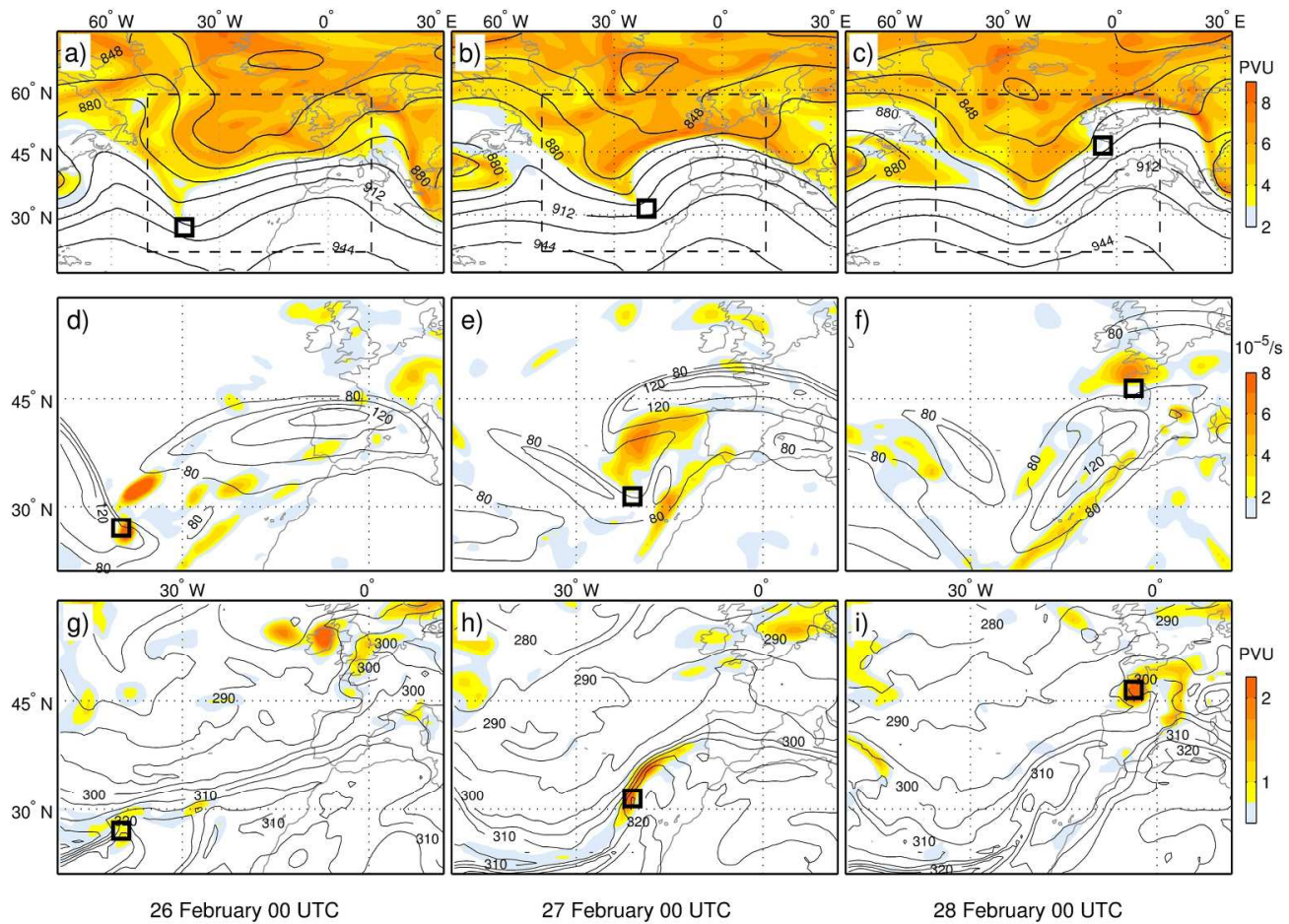

Figure 4. Synopsis of different meteorological parameters for three time steps during rapid intensification of Xynthia: left column 26 February 00 UTC; centre column 27 February 00 UTC; right column 28 February 00 UTC. (a)-(c): PV-distribution [PVU] (shaded) on the $320 \mathrm{~K}$ isentropic level and geopotential height at 300 $\mathrm{hPa}$ (black isolines with an interval of $16 \mathrm{gpdm}$ ); (d)-(f): jet stream [kts] (isolines) and divergence $\left[10^{-5} \mathrm{~s}^{-1}\right]$ (shaded) at $300 \mathrm{hPa}$; (g)-(i): PV-distribution [PVU] (shaded) and equivalent potential temperature $\Theta_{e}[\mathrm{~K}]$ (contour lines, every $5 \mathrm{~K}$ ) at $850 \mathrm{hPa}$. Please note that (d)-(i) are zoomed to the dashed box as shown in (a)-(c) for better representation of synoptic scale variables. In all panels the black squares mark the location of the surface cyclone.

This article is protected by copyright. All rights reserved. 

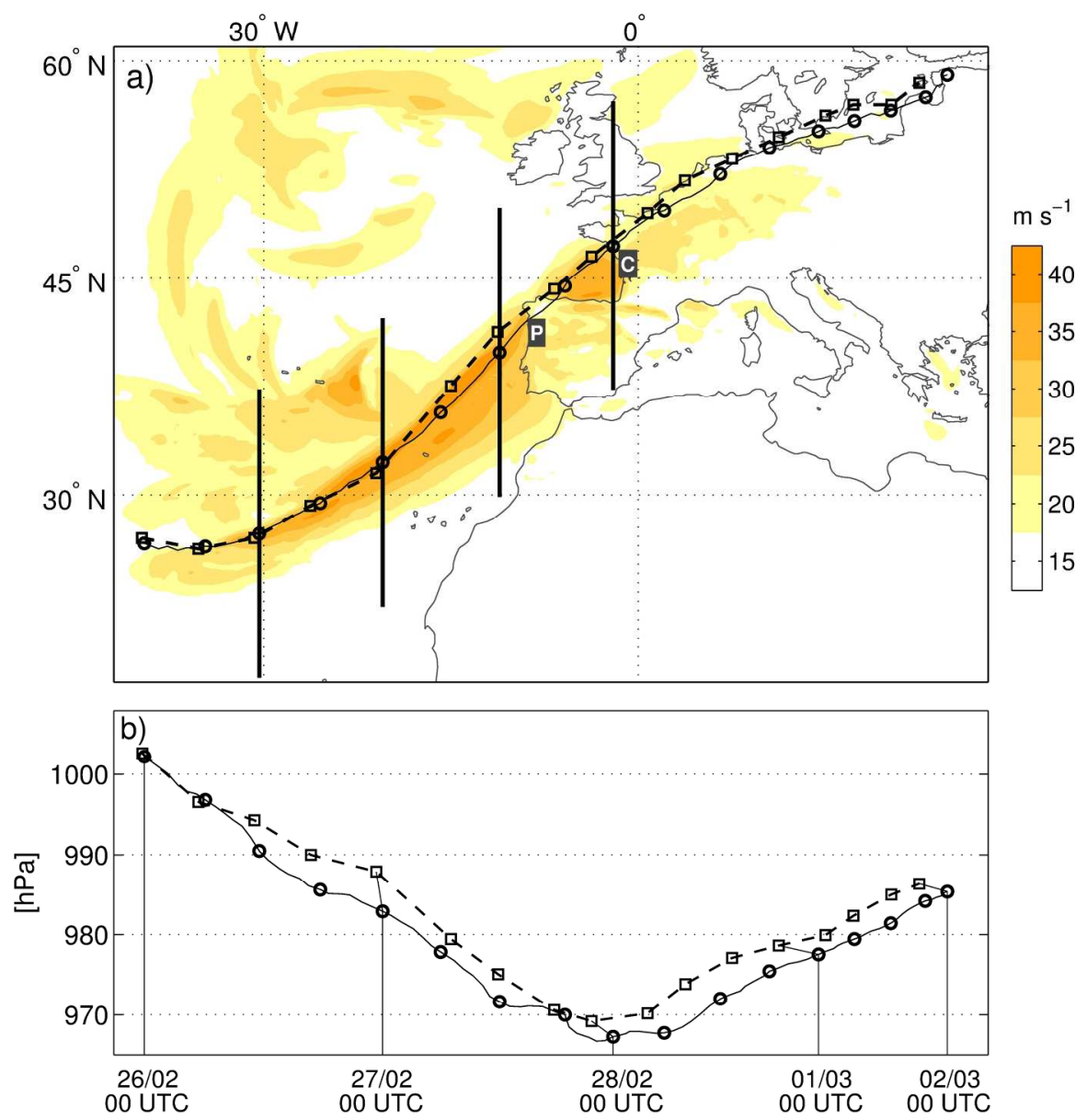

Figure 5. Cyclone location (a) and core pressure evolution (b) of Xynthia as derived from ERA-Interim (dashed line with squares) and CNTRL (solid line with circles). First depicted point is at 26 February 00 UTC. Squares/circles are in 6 hourly intervals until 02 March 00 UTC. (a): Shaded areas show wind signature of the storm (maximum wind gust above $17.5 \mathrm{~m} \mathrm{~s}^{-1}$ at each grid point during the considered period). Uppercase letters ' $P$ ' and ' $C$ ' indicate the locations of the synoptic stations Porto and Chassiron for further comparisons. The four vertical lines along the track assign the positions of north-south cross sections shown in Figure 11.

This article is protected by copyright. All rights reserved. 


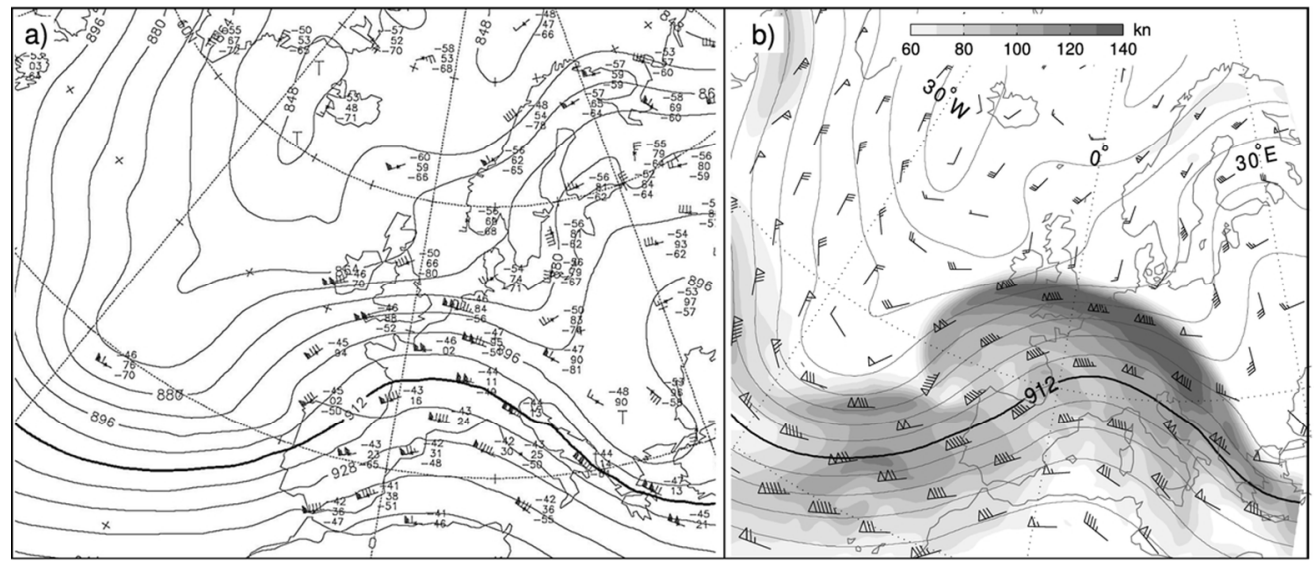

Figure 6. (a) Analysis of geopotential height [gpdm] (contours every $8 \mathrm{gpdm}$ ) and wind vectors by DWD at $300 \mathrm{hPa}$ on 27 February 12 UTC; (b) as (a), but for CNTRL. Wind speeds higher than 60 knots are shaded in intervals of 10 knots for clarification of upper level jet stream conditions in CNTRL.

This article is protected by copyright. All rights reserved. 

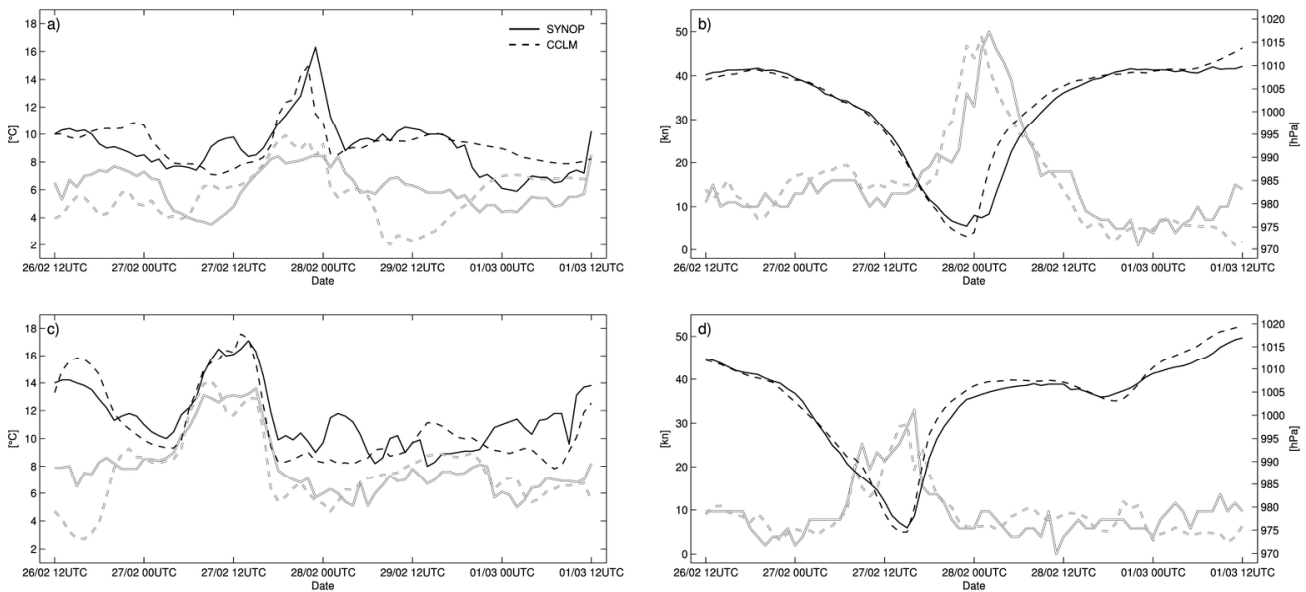

Figure 7. Time series for different meteorological parameters at two different locations for CNTRL (dashed line) and synoptic stations (solid line). (a): 2-metre temperature (black, $\left[{ }^{\circ} \mathrm{C}\right]$ ) and dew point temperature (grey, $\left[{ }^{\circ} \mathrm{C}\right]$ ) for CCLM grid point $164,134\left(1.20^{\circ} \mathrm{W}, 46.11^{\circ} \mathrm{N}\right)$ and synoptic station 07314 (Chassiron, $\left.1.41^{\circ} \mathrm{W}, 46.05^{\circ} \mathrm{N}\right)$. (b) as (a), but for 10 -metre wind speed (grey, [kn]) and mean sea level pressure (black, $[\mathrm{hPa}]) .(\mathrm{c})$ as (a) but for CCLM grid point $140,111\left(8.55^{\circ} \mathrm{W}, 41.20^{\circ} \mathrm{N}\right)$ and synoptic station 08545 (Porto, $\left.8.68^{\circ} \mathrm{W}, 41.23^{\circ} \mathrm{N}\right)$. (d): as (c) but for 10 -metre wind speed (grey, [kn]) and mean sea level pressure (black, [hPa]). For station locations please refer to Figure 5.

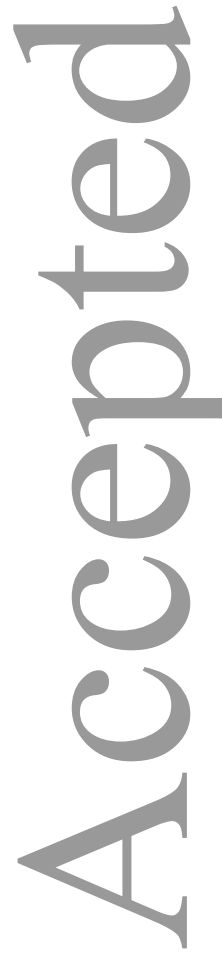

This article is protected by copyright. All rights reserved. 


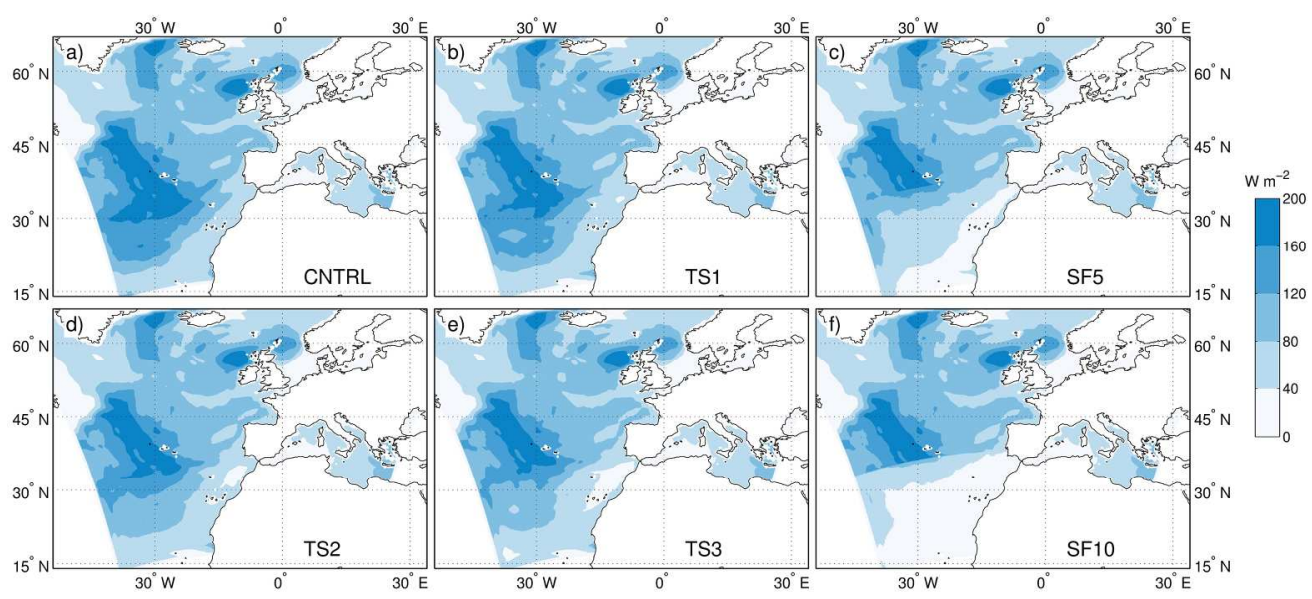

Figure 8. Averaged latent heat fluxes at sea surface (in $\mathrm{W} \mathrm{m}^{-2}$ ) for the period 26 February 2010,00 UTC to 28 February 2010, 00 UTC. (a) Undisturbed control simulation, (b) sensitivity study TS1 with $1 \mathrm{~K}$ reduction of SST, (c) sensitivity study SF5 with rlam_heat=5, (d) sensitivity study TS2 with $2 \mathrm{~K}$ reduction of SST, (e) sensitivity study TS3 with $3 \mathrm{~K}$ reduction of SST and (f) sensitivity study SF10 with rlam_heat $=10$. For more details see text.

This article is protected by copyright. All rights reserved. 

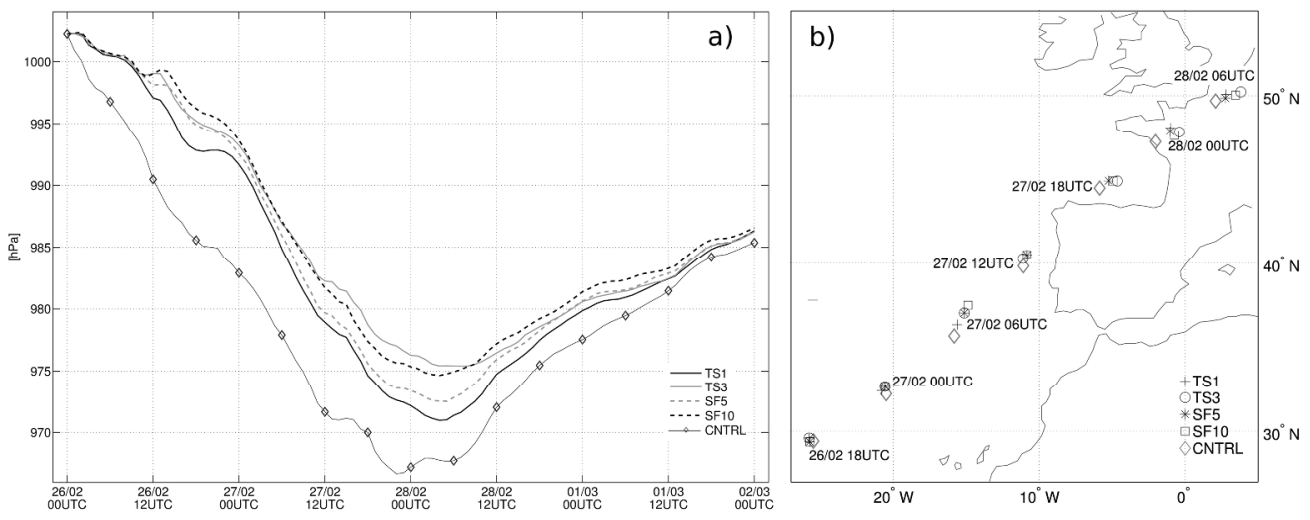

Figure 9. (a) Core pressure evolution and (b) cyclone locations for various sensitivity experiments. For better presentation of the results, only results for TS1 (black/plus symbol), TS3 (grey/circle), SF5 (stippled grey/asterisk) and SF10 (stippled black/square) are included. As reference, the core pressure evolution and location for the CNTRL (diamond symbols) are included.

This article is protected by copyright. All rights reserved. 

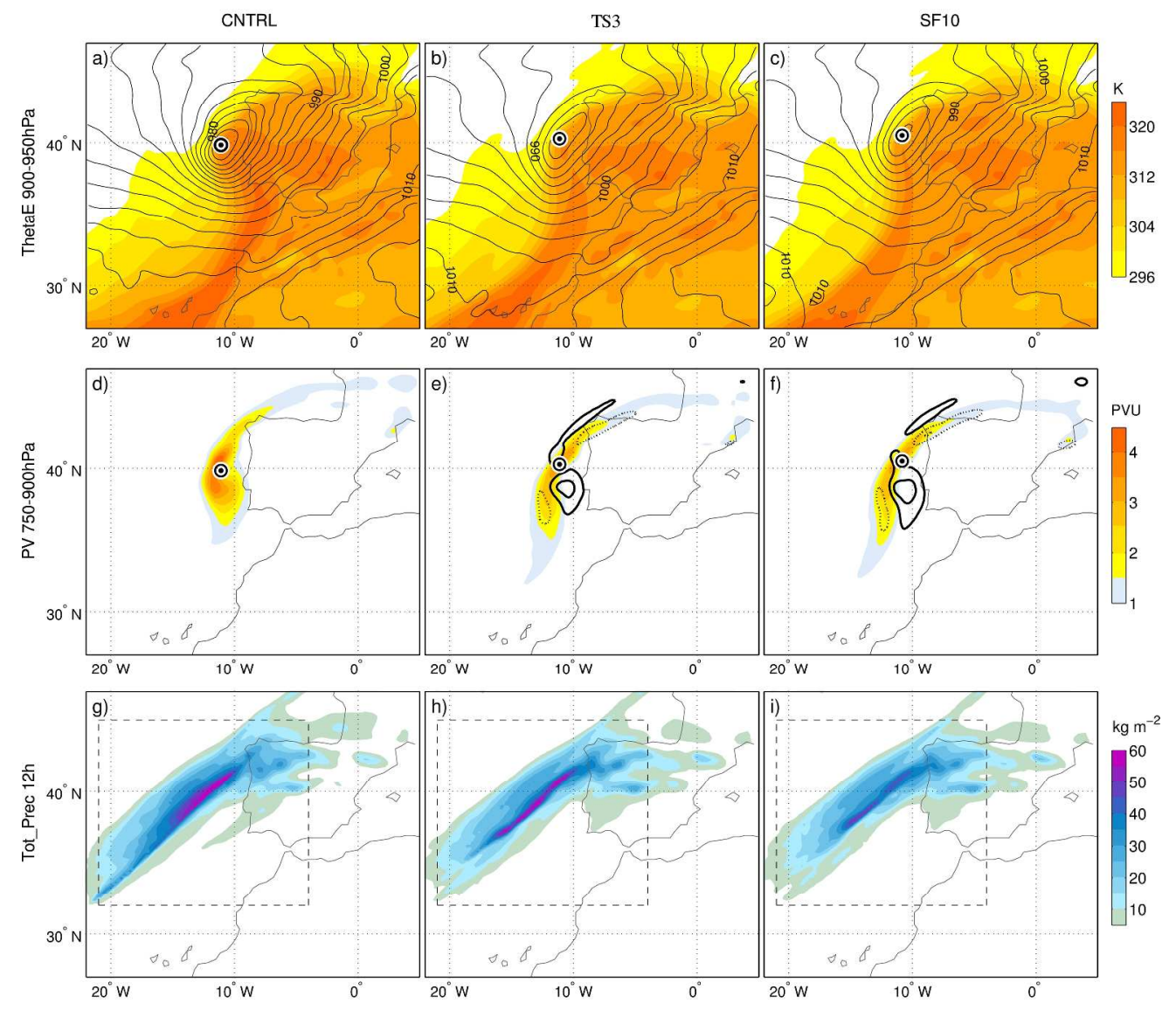

Figure 10. Top row: MSLP (contour each $2.5 \mathrm{hPa}$ ) and vertically averaged $\Theta_{e}$ between $900 \mathrm{hPa}$ and $950 \mathrm{hPa}$ on 27 February 12 UTC for (a) CNTRL, (b) TS3, and (c) SF10. Centre row: as (a) to (c), but for lowertropospheric PV vertically averaged between $750 \mathrm{hPa}$ and $900 \mathrm{hPa}$. (e) and (f) also show negative (positive) PV-differences of TS3-CNTRL and SF10-CNTRL contoured as thick (stippled) black lines respectively (contour each $1 \mathrm{PVU}$ ). For (a)-(f), black/white circles indicate corresponding cyclone position. Bottom row: as (a) to (c), but for 12-hour precipitation accumulation on 27 February between 00 UTC and 12 UTC. Comparative values for precipitation are calculated in the box marked by dashed line (see text for details).

This article is protected by copyright. All rights reserved. 

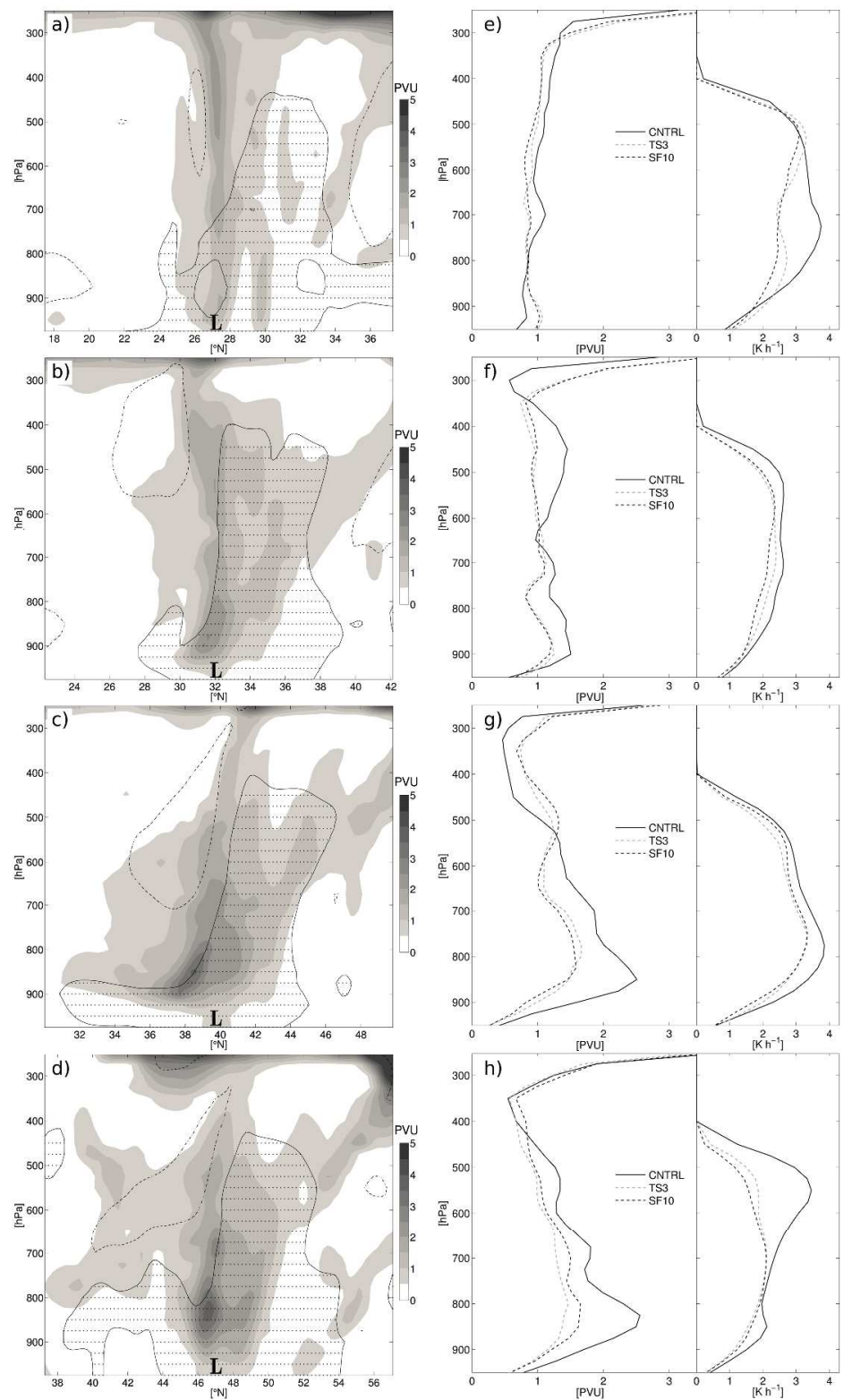

Figure 11. (a)-(d): South-north orientated vertical sections of the PV distribution [PVU] at different time steps (for positions of cross sections see Figure 5). PV and relative humidity (stippled isoline: $20 \% \mathrm{RH}$; dotted area: RH > 80\%) for CNTRL at a) 26 February 12 UTC, (b) 27 February 00 UTC, (c) 27 February 12

UTC and (d) 28 February 00 UTC. The location of the surface low is indicated by ' $L^{\prime}$. (e)-(h): Vertical distribution of horizontal averaged PV (left, [PVU]) and diabatic heating rate (right, $\left[\mathrm{K} \mathrm{h}^{-1}\right]$ ) over a $4^{\circ} \times 4^{\circ}$ box centred on the surface cyclone at different time steps for CNTRL (solid black line), TS3 (stippled grey line) and SF10 (stippled black line). Time steps in (e)-(h) according to (a)-(d).

This article is protected by copyright. All rights reserved. 